\title{
Saxophone Virtuosity: Manifestation and Effect in the Classical Saxophone Repertoire
}

\section{Reuben Chin}

\author{
A thesis \\ submitted to Victoria University of Wellington \\ in partial fulfilment of the requirements for the degree of \\ Master of Musical Arts in Performance
}

New Zealand School of Music

2017 
C Copyright by

Reuben Chin

All rights reserved

January 2017 


\begin{abstract}
To ascribe the word 'virtuosity' to a single and absolute definition is an impossible task. It is a term that is multifaceted in its meaning and which is understood differently in a variety of contexts. This thesis investigates how the word virtuosity has been used in music discourse, and then considers virtuosity in three aspects of saxophone performance: altissimo, fast finger technique and soloistic roles. The application of these three aspects of virtuosity to the classical saxophone repertoire is then examined. Specifically, I examine the application of altissimo in Jacques Ibert's Concertino da Camera for Alto Saxophone and Eleven Instruments; fast finger technique in the cadenzas of Pierre Max Dubois' Concerto for Alto Saxophone and String Orchestra and Alexander Glazunov's Concerto for Alto Saxophone and String Orchestra; and soloistic roles in classical saxophone orchestral repertoire. I also consider the relevance of the saxophone as a non-standard orchestral instrument to the notion of soloistic virtuosity. With these three aspects of virtuosity established, I explore the relationship between virtuosity and Claude Debussy's Rapsodie for Orchestra and Alto Saxophone. This exploration first demonstrates how adaptations made to the Rapsodie can be seen to increase the virtuosic nature of the work. Second, it looks at how these adaptations could be contradictory to the composer's intentions. Last, it considers the motivation and purpose behind these adaptations. The aim of this thesis is to disclose ways in which virtuosity may be understood in the context of the classical saxophone repertoire and how this understanding has affected Debussy's Rapsodie in particular.
\end{abstract}




\section{List of Acknowledgements}

First and foremost, thank you Hamish Robb. You have been a patient, encouraging and inspiring supervisor. Your guidance and feedback throughout this process have been invaluable. I couldn't have asked for anyone better.

Thank you Simon Brew - you have pushed me to tackle repertoire I didn't think I was capable of playing. You have developed a new and exciting side to my playing, and encouraged me to take every opportunity and make the most out of my course of study this year.

Thank you Debbie Rawson for your undying encouragement and positivity. You have always supported me $110 \%$. An extra, special thank you for being my scholarship referee (along with Donald Maurice) - without the Victoria Master's by thesis Scholarship this wouldn't have been possible.

Of course, thank you Mum and Dad for your love and support, and for being an extra pair of eyes to proofread bits and pieces for me.

And finally, thank you Patrick Webb for allowing me to bounce my ideas off you and helping me transcribe the cadenzas. 


\section{Contents}

Abstract

Acknowledgements $\quad$ iv

1. Defining Virtuosity 1

2. The Virtuosic Altissimo Register 7

3. Virtuosic Technique 13

4. Soloistic Virtuosity in Classical Saxophone Orchestral Repertoire 26

5. The Orchestral Saxophone 31

6. Debussy's Rapsodie: A Virtuosic Work? 35

7. Investigating the Imposition of Virtuosic Adaptations in Debussy's Rapsodie 43

8. Final Thoughts and Reflections 49

$\begin{array}{ll}\text { Bibliography } & 51\end{array}$

$\begin{array}{ll}\text { Appendix } & 55\end{array}$ 


\section{Defining Virtuosity in Music}

In music performance, the terms 'virtuosity' and 'virtuoso' are often used to describe the performer or the performance itself - but what is meant when these terms are used; what is trying to be conveyed? Do these terms have universal meaning, or are they understood differently by different cultural groups of people? Although such questions may be applied to any definition of any word, they are necessary for exploring the problematic issues when one engages with these particular terms. This thesis explores the various ways that these terms are understood, and investigates their application to some key works in the classical saxophone repertoire. In particular, I explore the relationship between virtuosity and Claude Debussy's Rapsodie, a staple saxophone work. This exploration specifically examines the virtuosic adaptations implemented in the Rapsodie to show how these adaptations may be potentially contradictory to the composer's intentions.

Before I began my research for this thesis, technique largely defined my preconceived idea of virtuosity - specifically, rapid successions of notes, a concept which is later discussed in section 3. My previous understanding of virtuosity also required a listening audience or receiver. The receiver, or listening audience, must experience and validate some degree of 'impressiveness' in response to the performer's technical display; without this validation, I thought, the performer's display is simply technical, not virtuosic. My preconceived definition of virtuosity thus connoted two things: impressiveness and technique. Notably, this notion of impressiveness in virtuosity is not unfamiliar. Leigh Hunt's definition of the nineteenthcentury virtuoso resonates with the idea of impressiveness, stating that a virtuoso is a performer whose 'technical accomplishments [are] so pronounced to dazzle the public'. ${ }^{1}$ Moreover, musicologist Francisco Monteiro illustrates that a virtuoso is someone who takes risks, and amazes and moves the audience. Virtuosity means 'to confirm a victory, to accept a challenge, to be amazed and moved by a performance' ${ }^{2}$

\footnotetext{
${ }^{1}$ Leigh Hunt, 'Paganini, the Spectacular Virtuoso', in Music in the Western World: A History in Documents, ed. Piero Weiss and Richard Taruskin, second edition (Belmont: Thomson Schirmer, 2008), 289.

${ }^{2}$ Francisco Monteiro, Virtuosity: Some (quasi phenomenological) thoughts (Porto: European Conservatories Association, 2007), 320.
} 
In these cases, the idea of dazzling or amazing the audience is the same as the act to impress. Renowned saxophonist Jean-Marie Londeix also describes a virtuoso performer as one who is 'seeking to attract and appeal to large audiences'. ${ }^{3}$ Similarly, French musicologist Marc Pincherle describes virtuosos as 'skilful performers [who] strove to please their audiences'. ${ }^{4}$ Again, both these cases link virtuosity with some positive and validating response from a listening audience. However, through the use of the terms 'seeking' and 'strove', these two definitions suggest an intention to evoke such a response from the audience. Given this, can a virtuoso still be considered a virtuoso if they please or impress an audience without intending to do so?

The question of what constitutes impressive also begs consideration. It could be said that the technical demands of a piece must be well-executed by the performer; audible mistakes and technical mishaps hinder the communication of impressiveness, thus, falling short as a display of virtuosity. However, the audience's experience and interpretation of what is impressive is subjective. For any number of reasons, an audience may not experience a performance as impressive, despite a perfect technical execution. In this regard, how does one differentiate between a thrilling and exciting display of technical virtuosity, and a robotic, monotonous technical exercise? The article by Associate Professor Arnie Cox 'Embodying Music: Principles of the Mimetic Hypothesis', offers an interesting light on this by examining how the body plays a role in constructing meaning in music performance. ${ }^{5}$ If movements, gestures, body language and stage presence of a performer affect how a listener hears and experiences music, then these movements and gestures could also be seen to contribute to a listener's experience of being impressed. A performer could, therefore, embody elements of virtuosity in music performance in a number of ways. The use of spectacle as virtuosic display could be communicated in a performer lengthening their back to appear taller or larger; quick, jerk-like gestures which move the performer's instrument up and down or side to side; or an exaggerated cut-off

\footnotetext{
3 James C. Umble, Jean-Marie Londeix: Master of the Modern Saxophone (New Jersey: Roncorp Publications, 2000), 264.

${ }^{4}$ Marc Pincherle, 'Virtuosity', The Musical Quarterly 35/ 2, trans. Willis Wager (1949), 230.

${ }^{5}$ Arnie Cox, 'Embodying Music: Principles of the Mimetic Hypothesis', Music Theory Online 17/2 (2011) <http://www.mtosmt.org/issues/mto.11.17.2/mto.11.17.2.cox.html> (accessed 11 November 2016).
} 
gesture that ends a phrase or piece of music - like a violinist's finishing bow flick or a pianist launching their hands off the piano on the final chord. These gestures may add or increase senses of grandeur, excitement, or intensity; they may exaggerate the listener's experience of a piece of music, giving the illusion that elements sound faster, louder, or more difficult than they are. They might also augment the audience's estimation of the amount of effort involved in producing such sounds, leading to a sense of striving or stoicism. Such effects could, therefore, contribute to how a listener experiences impressiveness in a musical performance. This sentiment is highlighted by Monteiro, who discusses the importance and meaningfulness of the body for performers, performances and listeners. ${ }^{6}$ Robert Schumann's review of a performance by Liszt further illustrates the importance of spectacle in music:

The demon began to flex his muscles. He first played along with them, as if to feel them out, and then gave them a taste of something more substantial until, with his magic, he had ensnared each and every one and could move them this way or that as he chose. It is unlikely that any other artist, excepting only Paganini, has the power to lift carry and deposit an audience in such high degree... in listening to Liszt are we overwhelmed by an onslaught of sounds and sensations... it simply has to be heard - and seen. If Liszt were to play behind the scenes a considerable portion of the poetry would be lost. ${ }^{7}$

A 2014 review by Hazel Rowland of the twenty-four-year-old pianist Haochen Zhang is also notable in that it suggests that virtuosic performances are often associated with gestures and movements:

...Though Liszt demands a high level of virtuosity, Zhang avoided flamboyant gestures or distracting showmanship...8

Rowland's descriptions of 'flamboyant' and 'distracting', however, point to a negative view of virtuosity. This view can be understood as superficial virtuosity - virtuosity that

\footnotetext{
${ }^{6}$ Monteiro, Virtuosity: Some (quasi phenomenological) thoughts, 318-319.

${ }^{7}$ Robert Walser, 'Eruptions: Heavy Metal Appropriations of Classical Virtuosity', Popular Music 11/3 (1992), 278.

${ }^{8}$ Hazel Rowland, 'Concert Review: Proms 2: A tentative orchestra but a dazzling soloist' (2014) https://bachtrack.com/de DE/review-proms-china-philharmonic-balsom-july-2014 (accessed 11 November 2016).
} 
is devalued for its supposed excessiveness, emptiness, lack of honesty, or lack of seriousness. This is a common perception of virtuosity which was particularly prominent in music criticism of the nineteenth century. Many musicians and writers during this period thought that these 'superficial' and 'mechanical' displays of virtuosity threatened music's status as an art form.$^{9}$ These negative descriptions of virtuosity, such as 'frivolous, meretricious and insubstantial', also worked to promote symphonic music as 'serious' music, and as a superior alternative. ${ }^{10}$ Undercurrents of this superficial virtuosity can be seen in Londeix's description of technical virtuosity in contemporary saxophone music as 'superlative'. ${ }^{11}$ Further, the article 'Virtuosity as a Performance Concept: A Philosophical Analysis' by philosopher Vernon A. Howard negatively describes virtuosity as 'excessive attention to technique or to the production of special effects in vocal or instrumental music' ${ }^{12}$ Associate Professor Dana Gooley similarly describes this negative view of virtuosity as 'cheap, superficial, dishonest and flashy, ${ }^{13}$ adding that virtuosity of this nature in the nineteenth century was criticised for its 'excessive egotism'. ${ }^{14}$

Finally, if my preconceived idea of virtuosity construed impressive technique, then it consequently rejected slow, lyrical playing as virtuosic. Should this be the case? Can lyrical playing not be experienced as virtuosic? Musicologist Alexander Stefaniak suggests the idea of an 'inward virtuosity', which the pianist Adolf von Henselt achieved through a use of lyricism. This 'inward virtuosity' was not seen as superficial, but rather as an attractive, appealing form of virtuosity that transcended such superficiality. ${ }^{15}$ Further to this idea, Monteiro claims that virtuosity can be achieved at very fast or very slow speeds, as long as the audience interprets the performance as an

\footnotetext{
${ }^{9}$ Alexander Stefaniak, Schumann's Virtuosity: Criticism, Composition, and Performance in NineteenthCentury Germany (Bloomington: Indiana University Press, 2016), 2.

${ }^{10}$ Dana Gooley, 'The Battle Against Instrumental Virtuosity' in Franz Liszt and His World, ed. Christopher Gibbs and Dana Gooley (New Jersey: Princeton University Press, 2006), 57; 76.

${ }^{11}$ Umble, Jean-Marie Londeix: Master of the Modern Saxophone, 107.

12 Vernon A. Howard, 'Virtuosity as a Performance Concept: A Philosophical Analysis', Philosophy of Music Education Review 5/1 (1997), 43.

${ }^{13}$ Gooley, 'The Battle Against Instrumental Virtuosity', 105.

14 Ibid., 99.

${ }^{15}$ Stefaniak, Schumann's Virtuosity: Criticism, Composition, and Performance in Nineteenth-Century Germany, 90-91.
} 
amazing musical performance. ${ }^{16}$ Thus, the notion of virtuosity does not exclude the slow nor the lyrical. Virtuosity can be as nuanced as a staccato bow stroke, ${ }^{17}$ or as straightforward as embodying speed and accuracy in music. ${ }^{18}$ Musicologist Michael Mauskapf has even written a dissertation on a 'collective virtuosity' - a concept that describes the performance of a work whose challenging musical language requires a heightened level of artistic teamwork. ${ }^{19}$ Further, according to Professor Susan Bernstein, the term 'virtuoso' can be traced back to the fifteenth-century Italian word for one possessing force and value in art, science, or war. Bernstein goes on to say that in French, German and English in the seventeenth century, a virtuoso came to mean someone of 'varied culture' and 'good taste'. It was not until the eighteenth century that virtuosity began to signify a 'special devotion to... technique in playing and singing music' ${ }^{20}$ Howard argues that virtuosity is not something that can be taught:

Both musicianship and technical proficiency, as conforming to acceptable standards, can be taught; virtuosity, precisely because it exceeds normal expectations and standards, cannot be taught. Like genius, [virtuosity] is learned, perhaps coached along, but not taught in the way that most elements of technique and musicianship can be taught. Virtuosity comes more by suggestion and example emanating from tradition than by instruction... virtuosity, therefore, is an achievement, not a skill... ${ }^{21}$

Howard also believes that poets, writers, stage directors, scene designers and impresarios cannot be virtuosos because they do not perform works. ${ }^{22}$

\footnotetext{
${ }^{16}$ Monteiro, Virtuosity: Some (quasi phenomenological) thoughts, 316-317.

17 Jack Erik Anderson, 'The Cellist's Right Hand: A Guidebook for Pedagogy and Practice', D.M.A. diss., University of Idaho (2001), 113.

${ }^{18}$ François Pachet, 'Musical Virtuosity and Creativity' in Computers and Creativity, ed. by Jon McCormack and Mark d'Inverno (Berlin: Springer Science \& Business Media, 2012), 117.

${ }^{19}$ Michael Mauskapf, 'Collective Virtuosity in Bartók's Concerto for Orchestra', Journal of Musicological Research 30/4 (2011), 267.

${ }^{20}$ Kevin McLaughlin, 'Reviewed Work: Virtuosity of the Nineteenth Century: Performing Music and Language in Heine, Liszt, and Baudelaire by Susan Bernstein', Comparative Literature 53/2 (2001), 181.

${ }^{21}$ Howard, 'Virtuosity as a Performance Concept: A Philosophical Analysis', 47.

22 Ibid., 51.
} 
As illustrated by French scientist François Pachet in the opening of his chapter 'Musical Virtuosity and Creativity', virtuosity cannot be ascribed to a singular definition - it is multifaceted in its meaning, appeal and in the way it is embodied:

There is no precise definition of virtuosity, but only a commonly accepted view that virtuoso (sic) are human beings that excel in their practice to the point of exhibiting exceptional performance. Virtuosity exists in virtually all forms of human activity. ${ }^{23}$

${ }^{23}$ Pachet, 'Musical Virtuosity and Creativity', 115. 
The following three sections explore particular aspects of virtuosity which have been, or can be, applied to areas of the classical saxophone repertoire.

\section{The Virtuosic Altissimo Register}

A prominent element of virtuosity in the classical saxophone repertoire is the use of the altissimo register. The altissimo register refers to notes above the standard range of the saxophone. Originally, this constituted anything above $f^{\prime \prime \prime}$. However, developments in the saxophone's key work in the twentieth century led to the creation of a $f \#^{\prime \prime \prime}$ key. $f \#^{\prime \prime \prime}$ is widely considered as the top note in the standard range of the saxophone, as exemplified in Claus Raumberger and Karl Ventzke's chapter 'Saxophone' from 'The New Grove Dictionary in Jazz', ${ }^{24}$ and in the book Saxophone Top Tones by American saxophonist Eugene Rousseau. ${ }^{25}$ It is necessary to acknowledge that more recent developments, specifically on the soprano saxophone, have led to the creation of a g'"' key. $\mathrm{g}^{\prime \prime \prime}$, however, is not yet considered as a part of the standard range of the saxophone. This section considers the significance of altissimo, specifically in Ibert's Concertino da Camera, and demonstrates how altissimo can be seen to increase the virtuosic nature of a work.

Jacques Ibert's Concertino da Camera for Alto Saxophone and Eleven Instruments was written in 1935. It was commissioned by the German-American saxophonist, Sigurd Raschèr, who had a reputation for commanding a larger than normal range of the saxophone at the time.${ }^{26}$ Raschèr, often accredited as being the primary force in expanding the saxophone's range into the altissimo register, ${ }^{27}$ also

\footnotetext{
${ }^{24}$ Claus Raumberger and Karl Ventzke, 'Saxophone', in Grove Music Online <http://www.oxfordmusiconline.com/subscriber/article/grove/music/24670> (accessed 18 October 2016).

${ }^{25}$ Eugene Rousseau, Saxophone High Tones, second edition (St. Louis: Lauren Keiser Music Publishing, 2002), iv.

${ }^{26}$ Alfred W. Cochran, 'Reviewed Work: An American Tribute to Sigurd Raschèr by Lawrence Gwozdz', American Music 20/2 (2002), 235; William Stuart Graves, 'An Historical Investigation of and Performance Guide for Jacques Ibert's Concertino da Camera', D.M.A. diss., University of Texas (1998), 41.

27 [Sigurd Raschèr] was a virtuoso performer who established the saxophone as a classical instrument and expanded its range to four octaves. [The Editors of Encyclopædia Britannica, 'Sigurd Raschèr' in Encyclopaedia Britannica Online <https://www.britannica.com/biography/Sigurd-Rascher>, (accessed 18 October 2016)].

Raschèr was distinguished for his brilliant agility, sweetness of tone and musical sensibility, and he extended the range of the saxophone by more than an octave above the conventional $f$. [George Gelles and Peter Schmelz, 'Raschèr, Sigurd' in Grove Music Online
} 
wrote a book called Top Tones for the Saxophone: Four-Octave Range. The text aimed to educate saxophonists on developing and achieving a four-octave range on the instrument. ${ }^{28}$ Consequently, composers commonly wrote works to include altissimo for Raschèr:

From his earliest days as a soloist Raschèr had been keen to exploit the extended range of the saxophone above its theoretical top note of f'"'... By devising a series of alternative fingerings to produce these high notes, Raschèr achieved considerable facility in this range, something that was often reflected in the pieces written for him. ${ }^{29}$

A few examples included the concerti written for him by Alexander Glazunov, Lars-Erik Larsson, and Ingolf Dahl; the Ballade by Frank Martin; Elegie et Rondo by Karel Husa; and Maurice Whitney's Introduction and Samba. As saxophonist Richard Ingham notes, Ibert's Concertino da Camera was no exception:

The influence his playing held over many composers is often evidenced by the inclusion of passages in the altissimo register, including perhaps most notoriously in the Concertino da Camera (1939) by Jacques Ibert. Raschèr's lifelong efforts passionately promoting the utilisation and mastery of the altissimo register have resulted in the acceptance of a range of over four octaves by both composers and performers. ${ }^{30}$

A review in La Revue Musicale of Raschèr's premiere performance of Concertino da Camera also suggests that the inclusion of altissimo was due to Raschèr's influence. ${ }^{31}$ Moreover, Londeix claims that the alternative cadenza in the Concertino da Camera which features an altissimo $g^{\prime \prime \prime}, b^{\prime \prime \prime}, c \#^{\prime \prime \prime \prime}, d^{\prime \prime \prime \prime}, e^{\prime \prime \prime \prime}$ and f'"', was a proposition by Raschèr. ${ }^{32}$

<http://www.oxfordmusiconline.com/subscriber/article/grove/music/22910>, (accessed 18 October 2016)].

${ }^{28}$ Sigurd Raschèr, Top-Tones for the Saxophone: Four-Octave Range, third edition (New York: Carl Fischer Music, 1983).

${ }^{29}$ Stephen Cottrell, The Saxophone (New Haven: Yale University Press, 2012), 252.

${ }^{30}$ Richard Ingham, The Cambridge Companion to the Saxophone (Cambridge: Cambridge University Press, 1999), 42.

${ }^{31}$ Graves, 'An Historical Investigation of and Performance Guide for Jacques Ibert's Concertino da Camera', 43-44.

${ }^{32}$ Umble, Jean-Marie Londeix: Master of the Modern Saxophone, 246. 


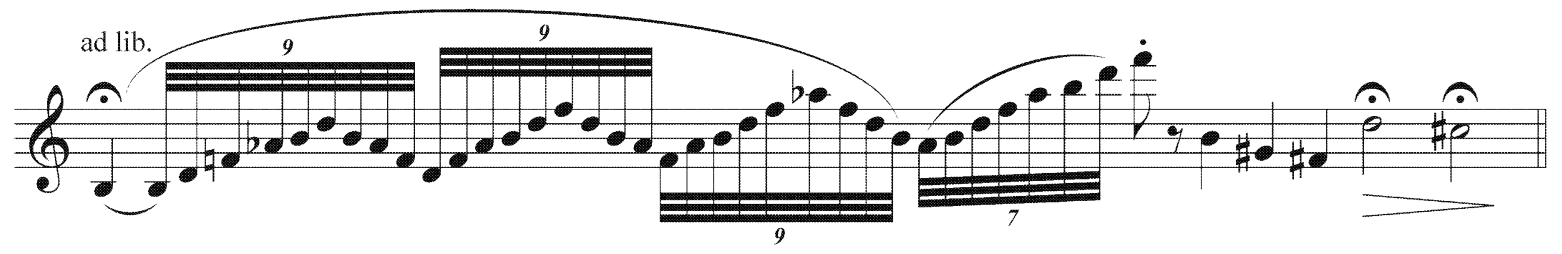

Cadenza, Concertino da Camera by Jacques Ibert

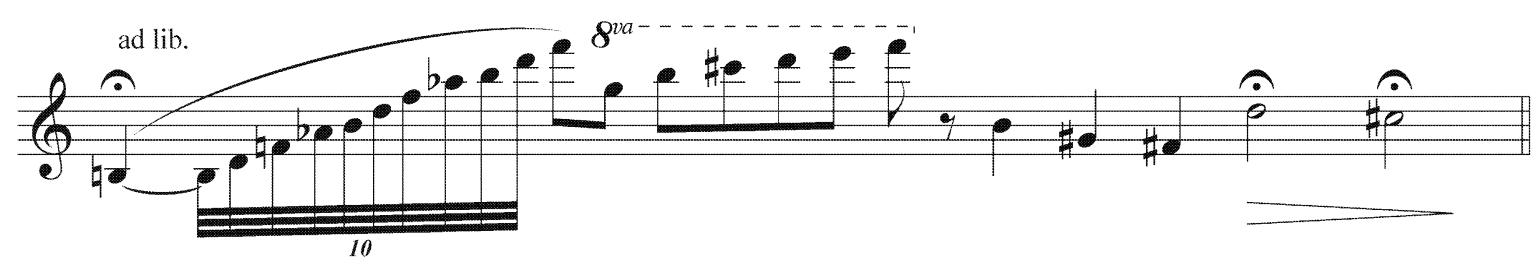

Alternative cadenza, Concertino da Camera by Jacques Ibert

The significance of altissimo in the Concertino da Camera, however, is only fully appreciated when its legitimacy is challenged. In an interview with Rousseau, French saxophonist Marcel Mule argues that the altissimo passages are not essential to the musical integrity of the work:

I performed the work without the altissimo notes, after having told Ibert that this was the only way I would do it. He told me it was fine with him, that he would not insist upon the high tones. In 1970 when I spoke in Geneva with Mr. Raschèr on the occasion of the International Saxophone Competition - we were both judges for this event - I told him of Ibert's position on the matter. At the Competition the Ibert Concertino had been played by a number of contestants without all of the high tones. Mr. Raschèr expressed his displeasure about this to me, stating that these performers were incorrect in leaving out all of the high register notes. But I explained to him that Ibert - who, after all, had been a dear friend of mine - told me that he had changed his mind completely on this subject since originally having accepted the commission from Raschèr. Ibert did not object to those who wished to perform his work with the high tones, but the inclusion of the altissimo notes was in no way a requisite for public performance of the Concertino da camera. If you look closely at the printed 
music, every high tone passage is marked ad libitum. This is precisely the way Ibert felt about this question; there is no doubt about it. ${ }^{33}$ In another interview, published in 'Australian Clarinet and Saxophone', Mule goes further to say that Ibert, in fact, preferred the Concertino da Camera without altissimo: Jacques Ibert was astonished by the high pitched notes but he changed his mind about it. He came to tell me one day that he had written a concerto. I had heard the first movement Larghetto and said: "you climb rather high, it is not quite my sphere at the moment." He told me "but I do not really want it." I played the Larghetto like that and I declared in Geneva that Jacques Ibert preferred it like that. ${ }^{34}$

If the absence of altissimo was considered preferable by Mule and Ibert in later years, what is the resulting effect when it is used in Concertino da Camera? In what follows, I consider how the use of altissimo in Ibert's Concertino da Camera, and in classical saxophone works at large, can be seen to increase the virtuosic nature of the work.

In Professor Alfred Cochran's review of Lawrence Gwozdz's 'An American Tribute to Sigurd Raschèr', Raschèr's propensity to ask composers to include altissimo notes is quoted to sometimes appear as an 'empty virtuosic display'. ${ }^{35}$ Regardless of whether altissimo or virtuosity is seen to have negatives effects on music, the description of altissimo here, as an 'empty virtuosic display', clearly demonstrates an association with virtuosity. Next, saxophone scholar Abraham Albertus de Villiers accredits Ibert's employment of the saxophone as a 'virtuoso instrument' in the Concertino da Camera to Raschèr's pushing of the envelope in terms of range. De Villiers goes on to say that composers, like lbert, explored the virtuosic capabilities of the saxophone through the exploration of its higher register. ${ }^{36}$ De Villiers also

\footnotetext{
${ }^{33}$ Eugene Rousseau, Marcel Mule: His Life And The Saxophone (Shell Lake: Etoile Music, 1982), 59.

${ }^{34}$ Claude Delange, 'Interview with the Legendary Marcel Mule on the History of Saxophone Vibrato', trans. Huguette Brassine (1998), 8 <http://clarinet-saxophone.asn.au/wp-content/uploads/interviewwith-Marcel-Mule.pdf> (accessed 8 August 2016). Note: this interview first appeared in the November, 1994 issue of APES (International Association for the Development of the Saxophone) and was translated for Australian Clarinet and Saxophone by Huguette Brassine, Senior Lecturer, Queensland Conservatorium.

${ }^{35}$ Cochran, 'Reviewed Work: An American Tribute to Sigurd Raschèr by Lawrence', 235.

${ }^{36}$ Abraham Albertus de Villiers, 'The development of the saxophone 1850-1950: its influence on performance and the classical repertory', M.M. diss., University of Pretoria (2014), 67.
} 
advocates that the technological developments in the 1930s and 1940s, which gave the saxophone the ability to play higher, added to the virtuosic nature of both performing saxophonists and compositions for saxophone. ${ }^{37}$ Lastly, De Villiers describes the Concertino da Camera as 'a virtuoso work that utilises the altissimo register' ${ }^{38}$ Darius Milhaud's review of Raschèr's premiere performance also suggests the use of altissimo as a virtuosic quality, ${ }^{39}$ while a number of other sources, not specific to Ibert's Concertino da Camera or Sigurd Raschèr, further link altissimo with virtuosity:

... for the saxophonist who chooses to be called a virtuoso, a range of at least three octaves is required. ${ }^{40}$

... I gradually increased the range of the selected etudes to encompass a full three-and-a-half octaves employed in the context of technically virtuosic writing. ${ }^{41}$

“...this work (Eric Coates' Saxo-rhapsody) makes no claims to profundity and, apart from two short passages and the final altissimo note, does not demand a virtuoso technique..." Notably, the author goes on to describe a saxophonist by the name of Dupaquier as a musician of great virtuosity who 'could play over a chromatic compass of three octaves from g'. He then describes another saxophonist, Texiero de Ladario, as 'an even more remarkable virtuoso' who commanded a compass of four full octaves. ${ }^{42}$

This plethora of evidence not only affords an understanding of altissimo virtuosity in Ibert's Concertino da Camera, but in the classical saxophone repertoire at large. It must be noted, however, that the majority of virtuosic-altissimo evidence drawn upon in this study comes from saxophonists themselves or musicians who are familiar with the saxophone. This may suggest that an embodied understanding or awareness of what it feels like to play in that register plays a significant part in

\footnotetext{
37 Ibid., 14; 69.

38 Ibid., 62.

${ }^{39}$ Graves, 'An Historical Investigation of and Performance Guide for Jacques Ibert's Concertino da Camera', 44.

${ }^{40}$ Kenneth Deans, "THE SAXOPHONE: A Soloist's Instrument", American Music Teacher 24/6 (1975), 31.

${ }^{41}$ Umble, Jean-Marie Londeix: Master of the Modern Saxophone, 123.

42 Wally Horwood, Adolphe Sax, 1814-94: His Life and Legacy (Baldock: Egon Publishers Ltd, 1983), 181.
} 
experiencing altissimo as virtuosic. From my own experience as a saxophonist, this is true. When I hear a saxophonist play altissimo I sometimes find myself empathising with the player in a physical way. My breath and chest open up and become more expansive. This is perhaps a reflection of the abdominal support, the speed of air, and openness of the throat required when playing altissimo. However, if I hear a struggle, strain or a cracking of a note in the altissimo register, then my body responds with tension and constriction. Moreover, my knowledge that the altissimo register is above the 'normal' or 'standard' register of the saxophone, and my understanding of the difficulty and skill required to execute altissimo has, without a doubt, contributed to my experience of it as virtuosic. This highlights two fascinating points about how one can understand virtuosity. First of all, it shows that for myself, an aspect of advanced skill or difficulty is necessary for how I experience virtuosity. Second, it poses the question: is altissimo felt as virtuosic by all listeners, and not just saxophonists? Of course, listeners who are unfamiliar with the technicalities of the saxophone can experience the altissimo register as virtuosic. Yet, not all listeners may experience altissimo this way. Without the understanding of the difficulty and skill required, or the feeling or embodied knowledge that any note above $f \#^{\prime \prime \prime}$ exceeds the normal range of the saxophone, what is it about the altissimo register that could make listeners experience it as virtuosic? 


\section{Virtuosic Technique}

An equally important view of virtuosity in the classical saxophone repertoire is rapid finger technique. This view stipulates that virtuosity is a group of notes played at a fast speed. Virtuosity of this form is commonly observed in bebop scholarship. Pachet demonstrates this clearly in his chapter 'Musical Virtuosity and Creativity'. He claims that virtuosity is essential to bebop music and that speed plays a substantial role in this virtuosity. He also defines virtuosic phrases as phrases that are 'played fast, typically $1 / 16^{\text {th }}$ notes at $120 \mathrm{bmp}$ or more, which represents at least 8 notes per second' ${ }^{43} \mathrm{His}$ subchapter 'Virtuosity Is to Improvisation as Running Is to Walking' states outright that virtuosity is about speed. Lastly, Pachet suggests further speed-based virtuosic sentiments through his definitions of virtuosity and technical virtuosity as 'the capacity to play interesting phrases fast', ${ }^{44}$ and 'the ability to play fast' ${ }^{45}$ respectively. This distinction between virtuosity and technical virtuosity is particularly intriguing as the latter lacks the idea of being 'interesting'. The use of the term 'interesting' could be seen as an extension of the idea of being musical or expressive. This would suggest technical virtuosity is somewhat boring, or mechanical in comparison to his definition of regular virtuosity. This further evokes the negative perception of a superficial virtuosity - something that sacrifices expression in pursuit of astonishment. ${ }^{46}$

Musicologist Guthrie Ramsey has described fast bebop melodies as requiring sheer virtuosity, ${ }^{47}$ which further strengthens the view of speed-based virtuosity. Similarly, Professor Stephen Cottrell connects speed and virtuosity in a description in his book The Saxophone:

Here [in bebop music] the saxophone is an explicitly virtuoso instrument, the hallmarks of the bop player being rapid finger technique... ${ }^{48}$

Outside of the jazz-bebop genre, these sentiments can also be observed in classical saxophone discourse. Alain Bouhey, a French saxophonist, recollects Londeix's

\footnotetext{
43 Pachet, 'Musical Virtuosity and Creativity', 120.

44 Ibid., 124.

45 Ibid., 133.

${ }^{46}$ Gooley, 'The Battle Against Instrumental Virtuosity', 76.

${ }^{47}$ Guthrie Ramsey, The Amazing Bud Powell: Black Genius, Jazz History, and the Challenge of Bebop (Oakland: University of California Press, 2013), 55.

${ }^{48}$ Cottrell, The Saxophone, 285.
} 
saxophone performances in Dijon as manifesting fabulous virtuosity. Bouhey explicitly defines this virtuosity in terms of the sextuplets from bars 138 to 152 in Dubois' Le lievre et la Tortue. ${ }^{49}$

Londeix's comments on the music of his colleagues also support the view of a speedbased virtuosity:

Those pieces responded to a certain need I felt, a desire to be able to show my agility and technical facility...It is true that I liked these pieces, and that I played them with much respect...But from a purely musical point of view I was frustrated and when I moved beyond the taste for sheer virtuosity in the early 1970 s this music was no longer of interest to me...50

Lastly, de Villiers describes fast note passages in the first movement of Ibert's Concertino da Camera as virtuosic. ${ }^{51}$
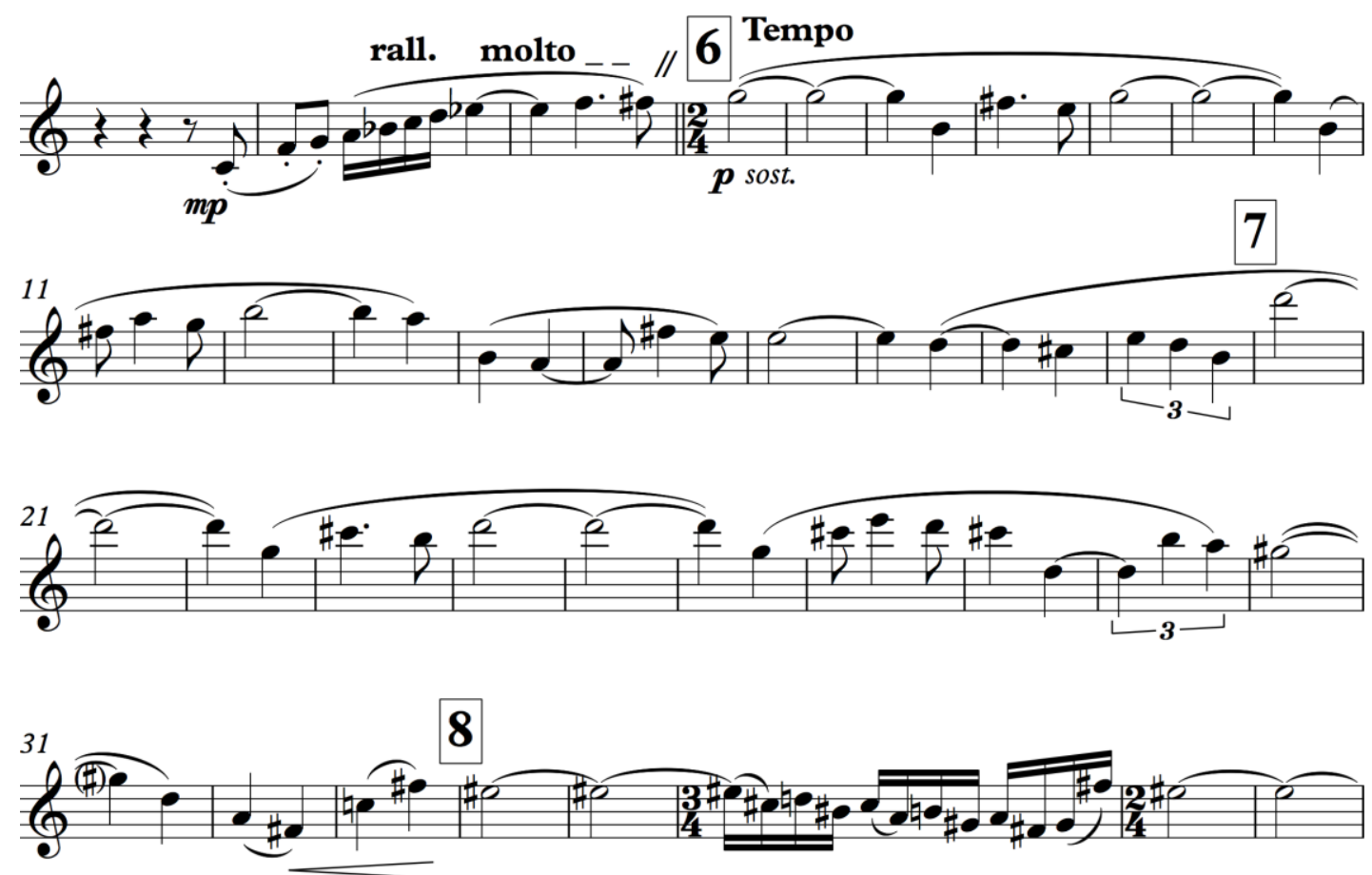

Excerpt of movement I, Concertino da Camera by Jacques Ibert

\footnotetext{
${ }^{49}$ Umble, Jean-Marie Londeix: Master of the Modern Saxophone, 57.

50 Ibid., 93.

${ }^{51}$ De Villiers, 'The development of the saxophone 1850-1950: its influence on performance and the classical repertory', 62.
} 
In the above example, De Villiers suggests the use of lyricism at rehearsal number 6 is a case of non-virtuosic playing. The contrasting semiquaver passage that ensues at 3 bars after rehearsal number 8 , however, is considered virtuosic.

Notably, Professor of English Eric Lott negatively describes this speed-based virtuosity in bebop music as 'ostentatious' ${ }^{52}$ American ethnomusicologist Paul Berliner, in quoting Melba Liston, similarly suggests that this technical dexterity can sometimes be seen as a display of empty virtuosity. ${ }^{53}$

The young players don't know what to do with their [unbelievable technique]. Sounds like they're playing computer music; it doesn't sound like ideas. It's all fast and furious. ${ }^{54}$

This quotation is interesting in that it suggests there is not enough time to hear thought-out ideas, and therefore one's musical artistry, in fast playing. Of course, this is not necessarily true as fast passages can be well considered by the performer. Nevertheless, this quotation reveals a perception that a musical idea needs time to be communicated and understood. This is further suggestive of the view that fast, technical virtuosity is superficial and lacks expression. Regardless of whether one supports or rejects this notion, it should be questioned why one often assumes that fast playing is not thought-out, sensitive, and artistic. In any case, these views suggest rapid finger technique as a form of virtuosity.

Pierre Max Dubois' Concerto for Alto Saxophone and String Orchestra, written in 1959 for the saxophonist Jean-Marie Londeix, is a work that demonstrates strong elements of this speed-based virtuosity - specifically through the adaptation of its cadenza. Disappointed with Dubois's original cadenza, Londeix suggested to Dubois that he write another one. However, Dubois was too busy to oblige, and instead, suggested that Londeix himself should write the cadenza. Londeix agreed, and the cadenza he wrote was well received by the composer. Consequently, the original

\footnotetext{
${ }^{52}$ Andrew Epstein, Beautiful Enemies: Friendship and Postwar American Poetry (Oxford: Oxford University Press, 2006), 295.

${ }^{53}$ Paul Berliner, Thinking in Jazz: The Infinite Art of Improvisation (Chicago: University of Chicago Press, 2009), 261.

${ }^{54} \mathrm{Ibid} ., 792$.
} 
cadenza by Dubois was removed and replaced by Londeix's cadenza for publication. ${ }^{55}$ The difference between these two cadenzas, in terms of this fast finger virtuosity, is striking. Dubois' original cadenza contains a total of 174 note changes. The fastest notated note values are semiquaver septuplets, which are present at the very beginning of the cadenza. Apart from the two groupings of semiquaver septuplets, the cadenza predominantly comprises semiquavers and quavers.
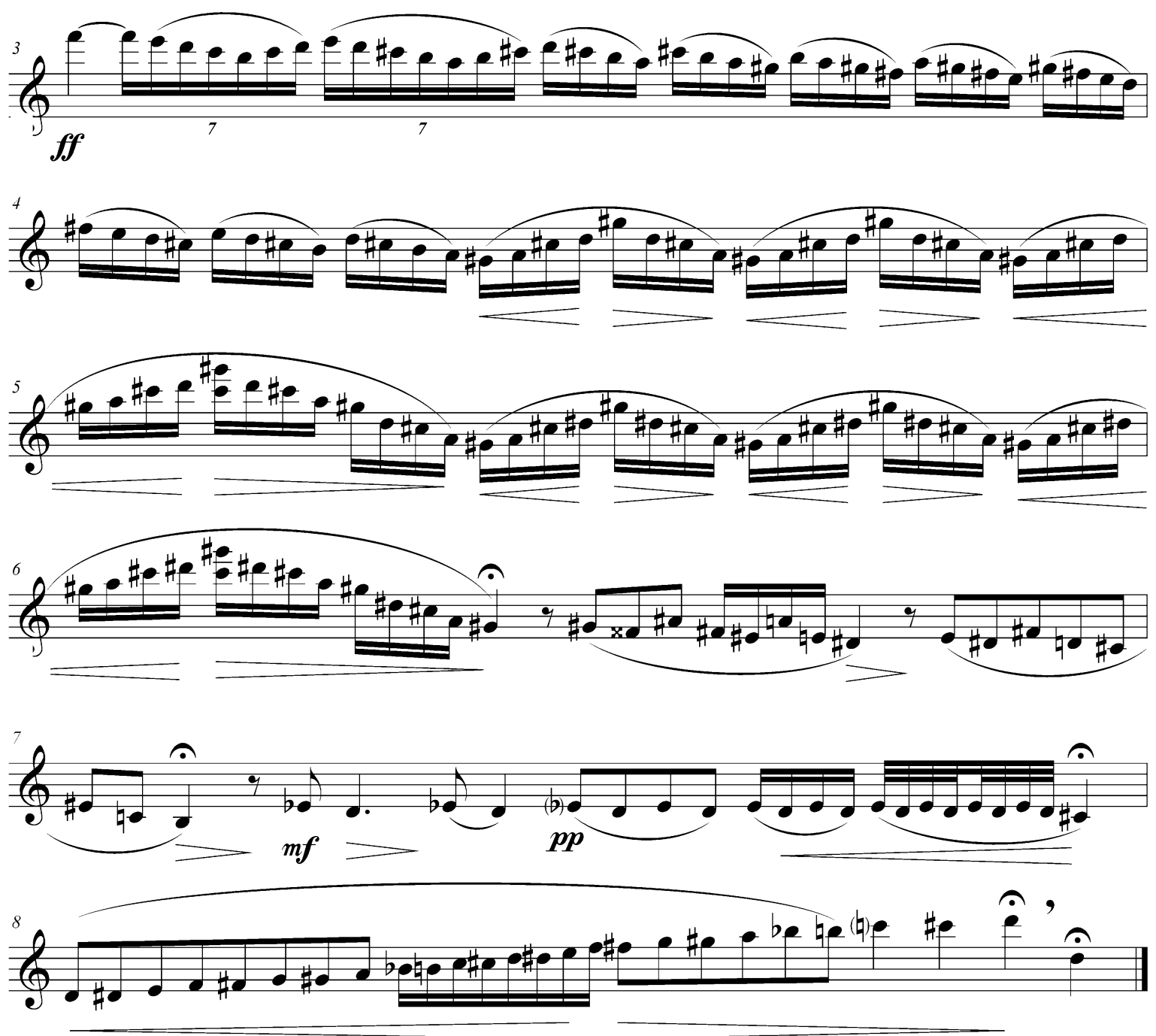

Original cadenza, Concerto by Pierre Max Dubois (see appendix)

On the other hand, Londeix's cadenza contains a total of 464 note changes. This is more than double the number of note changes in Dubois' original cadenza. More

${ }^{55}$ Umble, Jean-Marie Londeix: Master of the Modern Saxophone, 230. 
importantly, however, Londeix's cadenza uses much faster note values, and uses them more frequently. Semiquaver nonuplets, demisemiquaver nonuplets, demisemiquaver appoggiaturas, demisemiquaver thirteen-tuplets, demisemiquaver eleven-tuplets and demisemiquavers can be observed in Londeix's cadenza. The pinnacle of fast finger virtuosity in this cadenza are the 189 consecutive hemidemisemiquavers. 

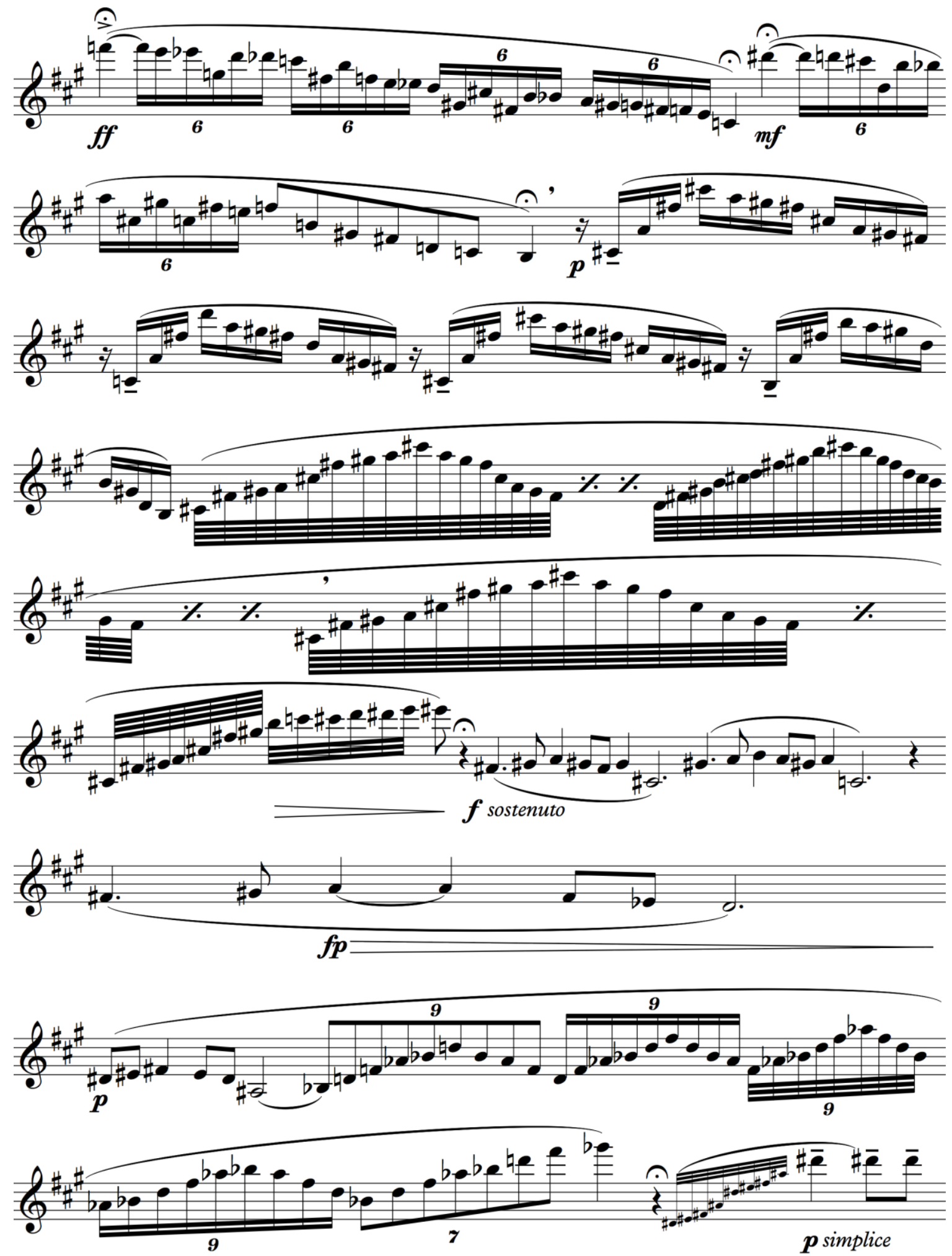

Londeix's cadenza, Concerto by Pierre Max Dubois 

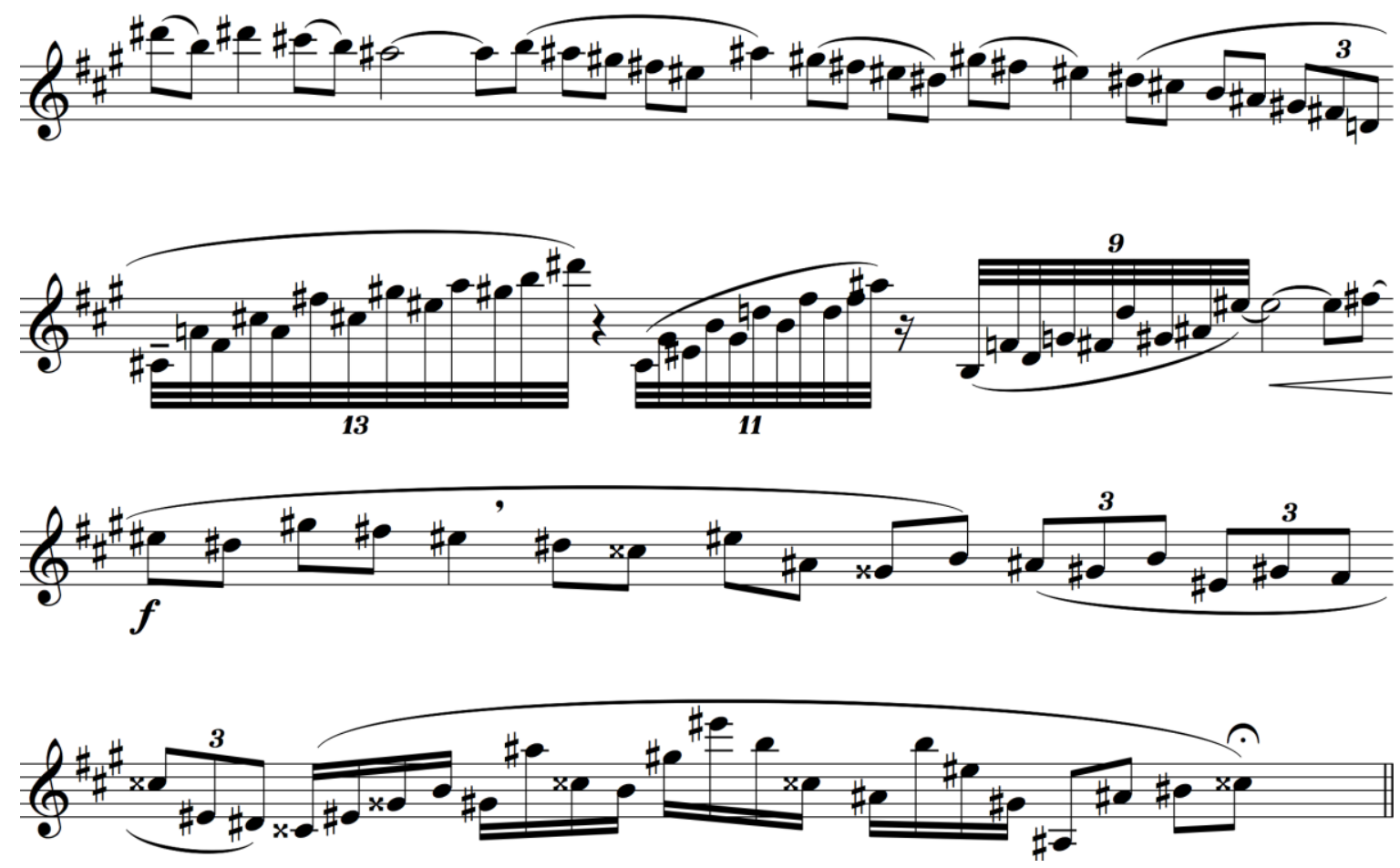

Londeix's cadenza continued, Concerto by Pierre Max Dubois

The arrangements of notes used in Londeix's cadenza are also more technically complex and difficult than the original. Dubois' original cadenza uses a lot of stepwise and repetitive movements. Londeix's cadenza, on the other hand, more often uses intervals of varying length - as close as chromatic or stepwise movement and as far as a compounded major second - which is technically more difficult to execute. Although this thesis does not specifically argue technical difficulty as a means of virtuosic display, it is nonetheless a plausible argument worth considering, especially in the context of Pachet's aforementioned definitions of virtuosity and technical virtuosity. If one considers 'interesting' as more complex or difficult then perhaps Dubois' original cadenza could be closer associated with technical virtuosity and Londeix's cadenza closer associated with virtuosity. Could one of these definitions be understood as more virtuosic than the other? Does technical complexity and difficultly affect the virtuosic degree of music? This thesis has argued that altissimo and fast finger technique can be seen as forms of virtuosic display - both of which are often considered difficult aspects of saxophone playing. This suggests a relationship between these virtuosic notions and difficulty that could be explored. Such questions further highlight the complexities and intricacies of the term virtuosity. Nevertheless, the more frequent and faster note 
values in Londeix's cadenza demonstrate higher fast finger virtuosity than Dubois' original cadenza.

Alexander Glazunov's Concerto for Alto Saxophone and String Orchestra, written in 1936, similarly shows clear elements of fast finger virtuosity. Again, this is best exhibited in a comparison between cadenzas - the original cadenza written by Glazunov and an alternate cadenza, written in 2010, by Christian Lauba. Like the Dubois cadenzas, the original cadenza of Glazunov's Concerto can been seen as less virtuosic, in terms of fast finger technique, than the alternate cadenza.
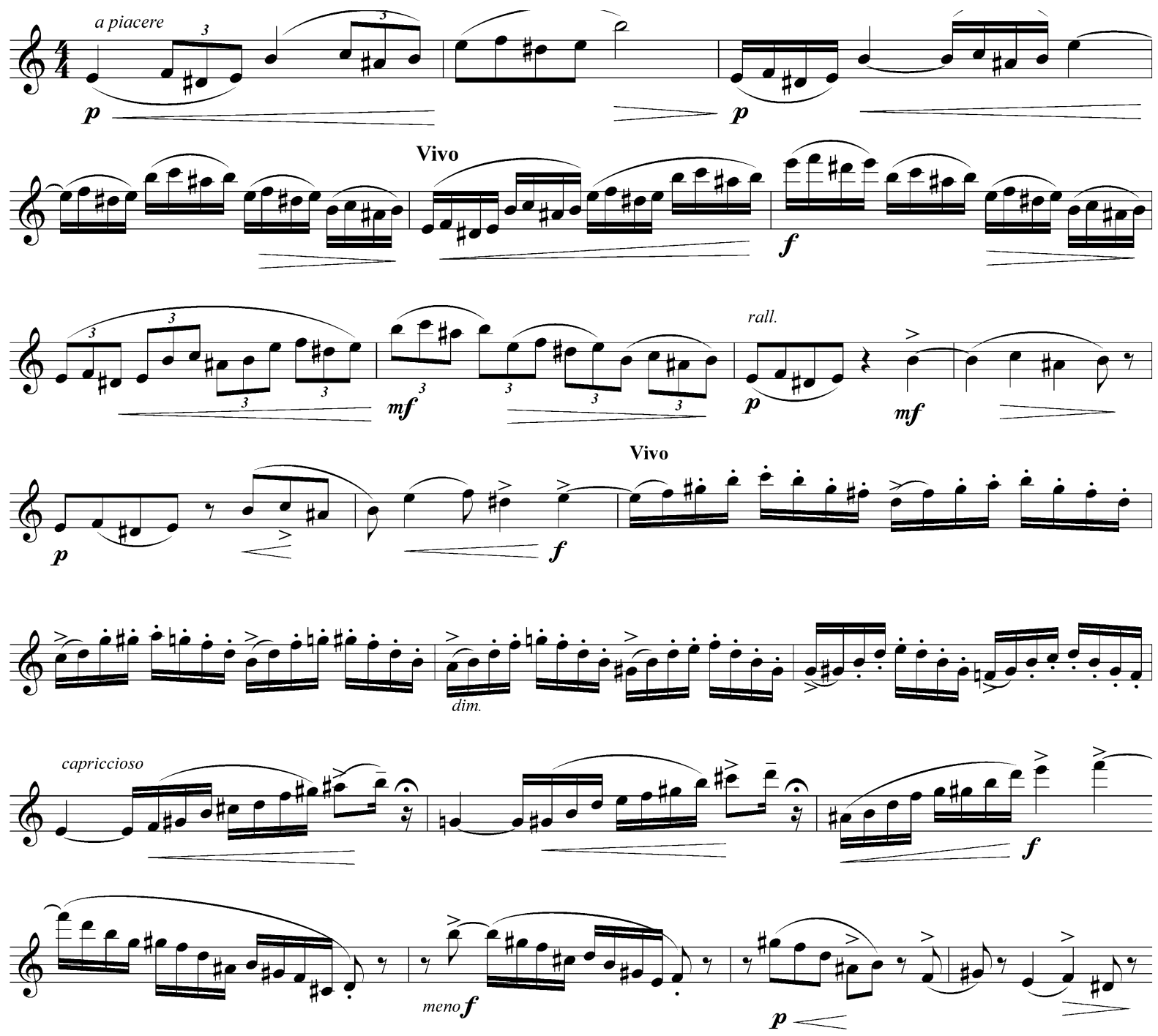

Original cadenza, Concerto by Alexander Glazunov

The original cadenza uses semiquavers as the fastest note value. The Lauba cadenza, however, features a frequent use of semiquaver quintuplets, semiquaver sextuplets, semiquaver septuplets, demisemiquavers, and demisemiquaver nonuplets. It must be 
noted, though, that the tempo marking in the original cadenza is moderato which then accelerandos to vivo. The tempo marking in Lauba's cadenza is marked lento. Thus, it could be argued that although Lauba's cadenza features faster note values, the slower tempo reduces its degree of fast finger virtuosity. Lauba's cadenza has a marked accelerando on line 1 and line 4, however, with no indication of slowing down until line 13. Depending on how fast the performer chooses to accelerate, he or she could easily surpass the displays of fast finger virtuosity in Glazunov's original cadenza. The high frequency of faster note values in Lauba's cadenza, however, can offer a more extensive opportunity to showcase fast finger virtuosity than the original cadenza.
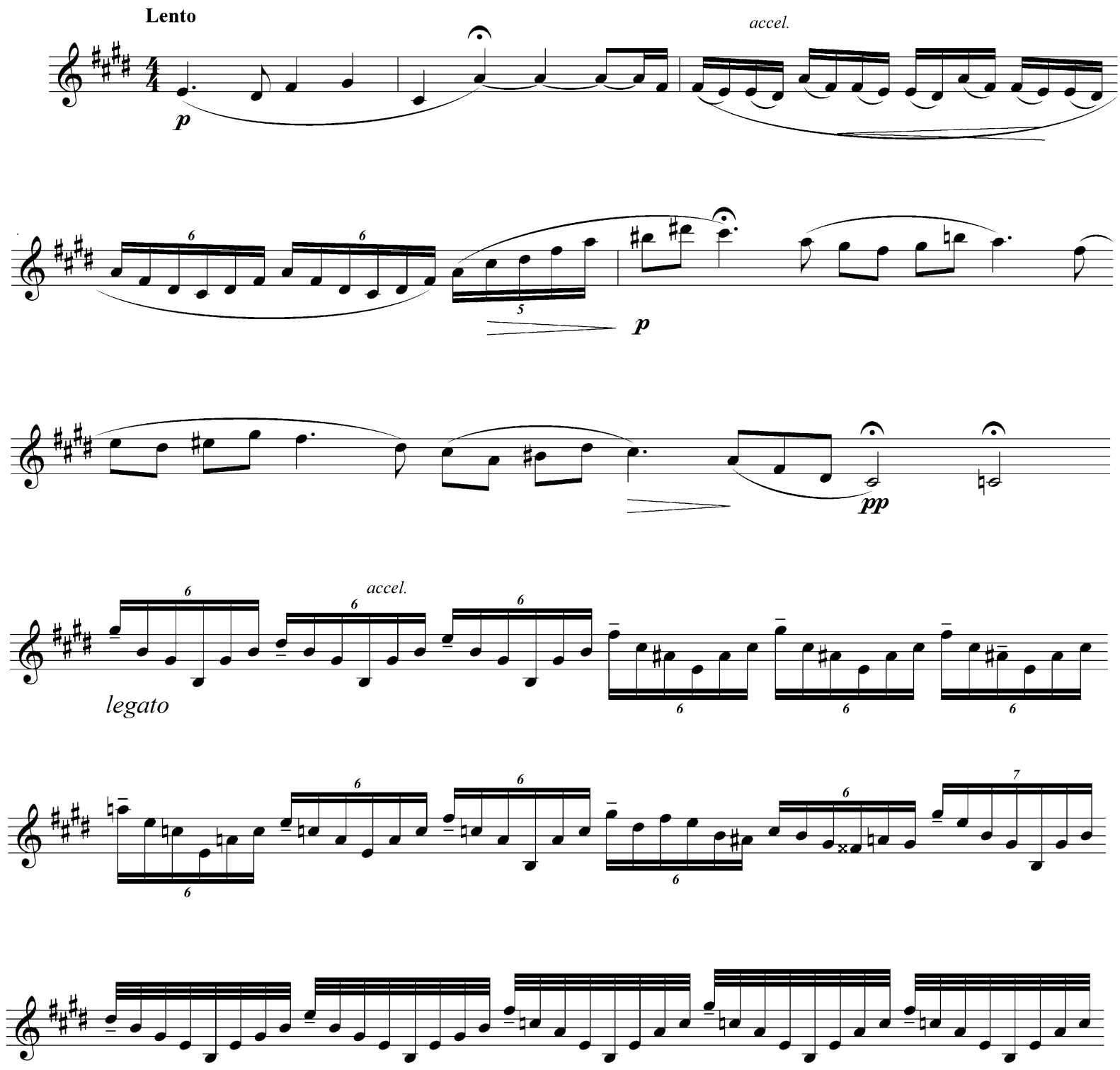

Lauba's cadenza, Concerto by Alexander Glazunov 

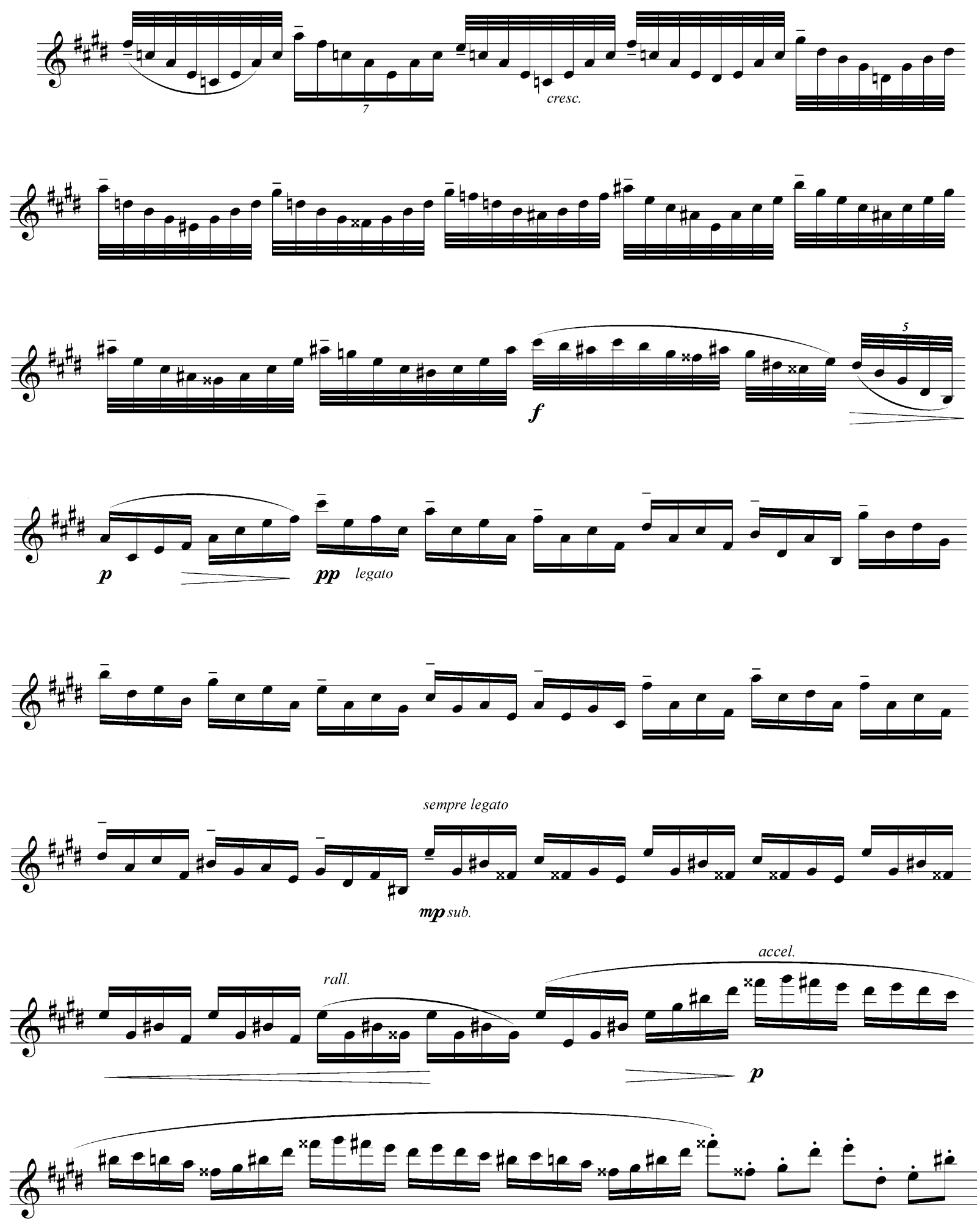

Lauba's cadenza continued, Concerto by Alexander Glazunov 

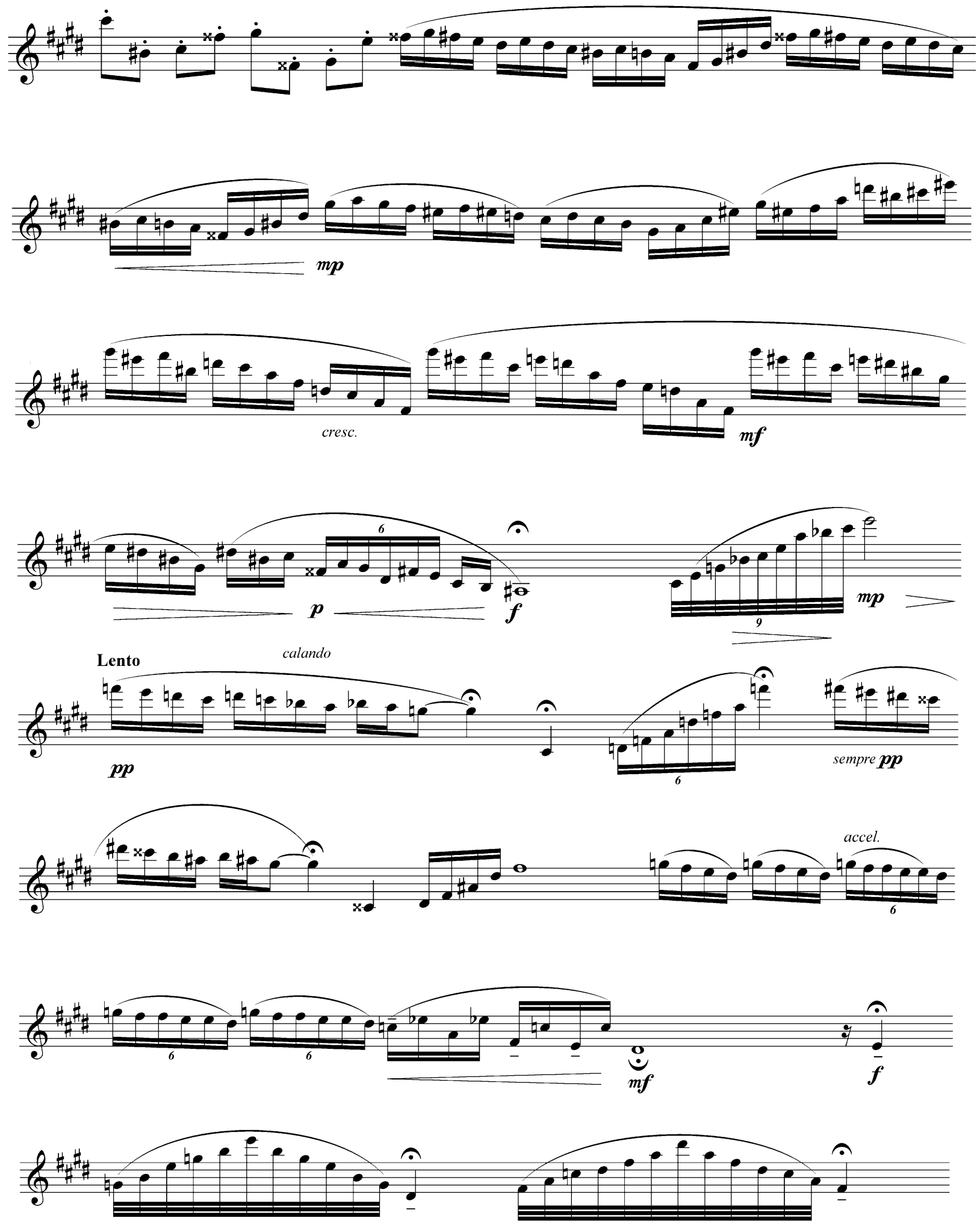

Lauba's cadenza continued, Concerto by Alexander Glazunov 

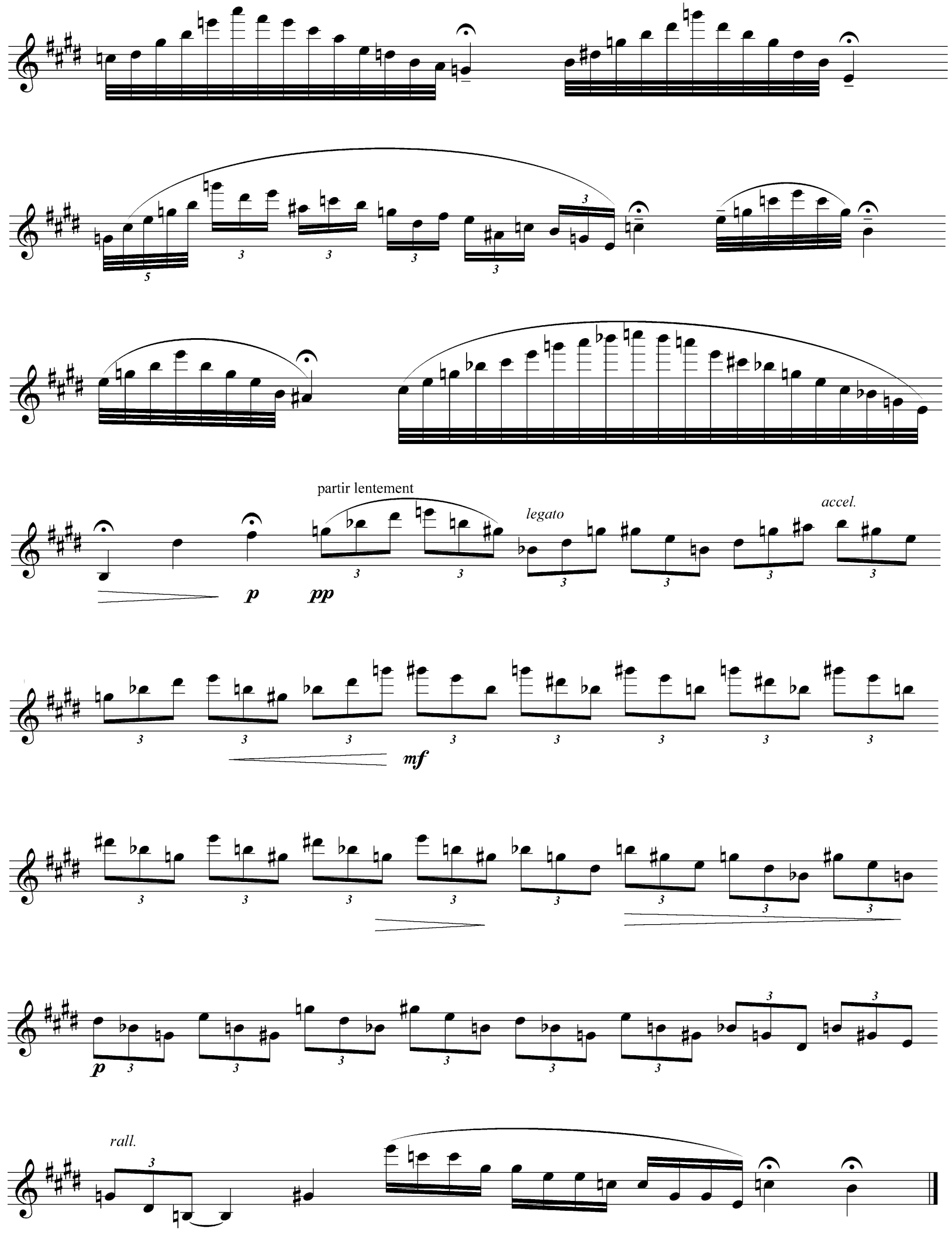

Lauba's cadenza continued, Concerto by Alexander Glazunov 
It should also be noted that, unlike the original cadenza, Lauba's cadenza features a strong use of altissimo. The Lauba cadenza requires the saxophonist to play altissimo $g^{\prime \prime \prime}, g \#^{\prime \prime \prime}, a^{\prime \prime \prime}, b b^{\prime \prime \prime}$ and an altissimo $c^{\prime \prime \prime \prime}$. In regards to altissimo virtuosity, Lauba's cadenza could, again, be seen as more virtuosic than the original. Lastly, Lauba's cadenza is significantly longer than the original. This means that the performer is in the solo spotlight for a longer period of time. The following section discusses how such soloistic features can also be considered virtuosic. 


\section{$\underline{\text { Soloistic Virtuosity in Classical Saxophone Orchestral Repertoire }}$}

The third and final view of virtuosity that this paper considers is the notion of a soloistic virtuosity - virtuosity defined by the use of a solo role. Specifically, I consider the manifestation and significance of soloistic virtuosity within the classical saxophone orchestral repertoire.

A direct link between virtuosity and soloistic performance can be observed in Gooley's chapter 'The Battle Against Instrumental Virtuosity' through an antithesising of instrumental music against symphonic music. According to Gooley, a growing attitude in the nineteenth century positioned instrumental music such as variations, potpourris, fantasies and concertos as 'dilettantish' music. This 'dilettantish' instrumental music was seen to be in opposition to 'serious' symphonic music. ${ }^{56}$ From this opposing binary, Gooley then connects instrumental music with the notion of soloistic virtuosity in a discussion of the Philharmonic Society of London:

An early, unambiguous antagonism between virtuosity and "serious" musical values is found in the founding charter of the Philharmonic Society of London... In its first charter, the Foundation Book, the Philharmonic directly linked its advocacy of symphonic works to the exclusion of soloist virtuosity. Concert programs, one statue stipulated, would consist of "the best and most approved instrumental music, consisting of Full Pieces, Concertantes for not less than three principal instruments, Sextetts, Quintetts and Trios; excluding Concertos, Solo, and Duets..." 57

Gooley establishes a clear opposition between virtuosity and serious music values in this discussion. She suggests that serious musical values were associated with symphonic music and, more importantly, that values of virtuosity were associated with works of a higher soloistic nature (concertos, solos, and duos). These works - or as Gooley coins them, 'virtuoso solos' - were banned. ${ }^{58}$ Furthermore, enthusiasm for such virtuosos was seen as 'unhealthy or misdirected' due to the egalitarian ideal that

\footnotetext{
${ }^{56}$ Gooley, 'The Battle Against Instrumental Virtuosity', 77.

${ }^{57}$ Ibid., 78.

58 Ibid., 78.
} 
all people are equal and deserve equal rights and opportunities. ${ }^{59}$ As Gooley states, this egalitarianism was also reflected through the exclusion of pieces that openly elevated a single performer above the group. ${ }^{60}$ This further strengthens why the symphony, a work in which no individual or section is singled out for very long, was seen as the antithesis of instrumental music that showcased soloistic virtuosity. Lastly, Gooley suggests that Liszt was able to avoid attacks from anti-virtuoso polemics in his solo piano concerts by drawing attention away from his 'isolated self' and highlighting either an aesthetic object (the work) or a social object (the public) instead. ${ }^{61}$ This suggests the notion of the soloist or 'isolated self' as an embodiment of virtuosity. Due to its soloistic nature and strong associations with virtuosity, the concerto form could be considered the epitome of soloistic virtuosity:

'In the late 18th century and during most of the 19th the solo concerto was a prominent form of virtuoso display... ${ }^{62}$

'The hissers were accusing the concerto of being an inferior type of music, corrupted by virtuosity'. ${ }^{63}$

Further, the musicologist John Irving illustrates that virtuosity was one of three characteristics that late eighteenth-century aestheticians required of a concerto. ${ }^{64}$ This soloistic virtuosity in the concerto form can also be applied to much of the classical saxophone orchestral repertoire, where the saxophone is also used in a soloistic manner. For the purposes of this paper, classical saxophone orchestral repertoire will be defined as orchestral works that include a single saxophone part. Soloistic treatment of the saxophone in orchestral works include:

L'arlésienne Suite No. 1 - Georges Bizet (1838-1875)

I. Ouverture: solo alto saxophone passage at 1 bar after Figure $\mathrm{E}$ II. Menuetto: solo alto saxophone passage at 4 bars after Figure B

\footnotetext{
${ }^{59}$ Gooley, 'The Battle Against Instrumental Virtuosity', 90-91.

60 lbid., 78.

61 lbid., 96.

${ }^{62}$ Arthur Hutchings, 'Concerto', in Grove Music Online

<http://www.oxfordmusiconline.com/subscriber/article/grove/music/40737> (accessed 11 December 2016).

63 Marc Pincherle, 'Virtuosity', The Musical Quarterly 35/2, trans. Willis Wager (1949), 236.

64 John Irving, 'Dazzling Concertos', Early Music 34/3 (2006), 487.
} 
IV. Carillon: solo alto saxophone passage at Figure D

L'arlésienne Suite No. 2

II. Intermezzo: solo alto saxophone passage at Figure B

III. Menuetto: solo alto saxophone passage at Figure F

Concerto for Piano and Orchestra - Aaron Copland (1900-1990)

Solo soprano saxophone passage at 5 bars before Figure 20

Solo soprano saxophone passage at 5 bars before Figure 26

Solo soprano saxophone passage at 1 bar before Figure 27

Solo soprano saxophone passage at Figure 44

Tableaux d'une expositon - Modest Moussorgsky (1839-1881), orch. by Maurice Ravel (1875-1937)

II. II vecchio castello: solo alto saxophone passage at Figure 20 (the entire saxophone part is more or less a solo)

Háry János Suite - Zoltán Kodály (1882-1967)

IV. The Battle and Defeat of Napoleon: solo alto saxophone passage at Figure 1 : solo alto saxophone passage at 1 bar after Figure 4 : solo alto saxophone passage at 12 bars before the end of the movement

Violinkonzert - Alban Berg (1885-1935)

Solo alto saxophone passage at 1 bar before Figure 25

Mouvement Symphonique No. 3 - Arthur Honegger (1892-1955)

Solo alto saxophone passage at Figure 17

Horizons - Arthur Shepherd (1880-1958)

II. The Lone Prairie: solo tenor saxophone passage at the beginning of the movement

Lions (A Dream) - Ned Rorem (1923- )

Solo alto saxophone passage at 11 bars before Figure 3

Sinfonia Da Requiem - Benjamin Britten (1913-1976)

I. Lacrymosa: solo alto saxophone passage at Figure 3

: solo alto saxophone passage at Figure 9 
II. Dies Irae: solo alto saxophone passage at 1 bar after Figure 26

Our Hunting Fathers

Solo alto saxophone passage at 1 bar after Figure 23

Solo alto saxophone passage at Figure 28

Uirapurú - Heitor Villa-Lobos (1887-1959)

Solo soprano saxophone passage at 5 bars before Figure 3 bis

Symphonic Dances - Sergei Rachmaninoff (1873-1943)

Solo alto saxophone passage at 4 bars before Figure 11 . Notably, in this work

the saxophone is used only in a solo role: the saxophone is tacet up until 4 bars

before Figure 11, where the solo begins. 23 bars later the saxophone solo ends

and the saxophone is tacet for the remainder of the first movement, and the entirety of the second and third movements.

Awakening and Dance of Ayshe - Aram Khachaturian (1903-1978)

Solo alto saxophone passage at Figure 5

Sabre Dance

Solo alto saxophone passage at 1 bar before Figure 5

Abstraction - Gunther Schuller (1925-2015)

Solo alto saxophone passage at 1 bar before Figure $C$

The Age of Gold - Dmitri Shostakovich (1906-1975)

II. Adagio: solo soprano saxophone passage at 2 bars after Figure 28

III. Polka: solo soprano saxophone passage at Figure 46

: solo soprano saxophone passage at 1 bar after Figure 47

In the case of Rachmaninov's Symphonic Dances, where the saxophone is used purely as a soloist, evidence of soloistic virtuosity becomes even stronger.

Furthermore, the use of texture, dynamics, register and vibrato within some of these orchestral works showcase the saxophone in a stronger soloistic light. Rachmaninov's Symphonic Dances uses a very thin accompanying texture in order not to overpower or drown out the solo saxophone. Throughout the entire saxophone solo only a singular flute, oboe or clarinet is ever used to accompany the saxophone. These singular accompanying woodwind parts are also marked at a $p p$ dynamic. Lastly, it is significant 
to note that all the accompanying lines sit in the middle registers of the flute, oboe, and clarinet so as to create a homogenous and complementary texture over the top of which the saxophone can easily sing.

In Ravel's orchestration of Mussorgsky's Tableaux d'une exposition, a similar use of thin accompanying textures is used. However, unlike Rachmaninov's Symphonic Dances, the saxophone is accompanied by strings. The accompanying violins, violas, cellos and double bass parts are all marked sourd which allows the saxophone to be more easily heard. An emphasis of vibrato is also marked in the saxophone part to allow it to further cut through as a solo voice. The virtuosic implications of these markings help shine a spotlight on the saxophone, while a shadow is cast over the rest of the orchestra.

Evidently, the manifestation of soloistic virtuosity in the classical saxophone orchestral repertoire is significant in its extent. This prevalence of soloistic writing shows that the saxophone can be seen as a virtuosic instrument in an orchestral context. However, had the saxophone established itself as a part of the standard orchestra, perhaps composers would have written for it differently - maybe in a less soloistic manner. This raises an important question of why the saxophone was unable to establish itself as a standard orchestral instrument. 


\section{The Orchestral Saxophone}

In addition to its late invention in 1840 by Adolphe Sax, a number of other factors can help explain why the saxophone was unable to become a standard member of the orchestra.

First, significant time is needed for composers, performers, and audiences to become fully acquainted with the capabilities and qualities of any new instrument. This is perfectly exemplified in a 1935 review of Sigurd Raschèr's first performance of Ibert's Concertino da Camera. The review claims that the saxophone has been very slow to establish its reputation, and that it is 'only today beginning to break down the resistance which has kept it from getting access to the symphony' ${ }^{65}$

Second, the novelty of the 'new' saxophone often saw it being talked about, and treated, as some musical 'other'. This can be seen in the description by English musicologist Winton Dean, of the saxophone's timbre as 'strangely haunting' ${ }^{66}$ Hector Berlioz's description of the bass saxophone in his orchestral treatise also reflects a strong sense of novelty:

As for its sound, I know of no other bass instrument in current use with which it can be compared... Its character is really quite new, with no resemblance to any of the sounds heard in the orchestra today with the possible exception of the bass clarinet's low F. ${ }^{67}$

Berlioz can be seen to link the saxophone with ideas of 'otherness' through his description of the instrument's bottom range as 'unusual' and 'unique'. He also advocates the saxophone as suiting pieces of a 'mysterious' character. ${ }^{68}$ Although Berlioz was an avid supporter of the saxophone, his descriptions suggest somewhat of an unfamiliarity with the instrument - something that was surely shared by many. This lack of familiarity and knowledge about the instrument may have been discouraging for composers - in section 7 I suggest that this was, in fact, the case for Debussy. If

\footnotetext{
${ }^{65}$ Graves, 'An Historical Investigation of and Performance Guide for Jacques Ibert's Concertino da Camera', 43.

${ }^{66}$ Cottrell, The Saxophone, 230.

${ }^{67}$ Hector Berlioz, Berlioz's Orchestration Treatise: A Translation and Commentary, ed. Hugh MacDonald (Cambridge: Cambridge University Press, 2002), 297.

68 Ibid., 298.
} 
composers were unlikely to write for the saxophone, the saxophone was unlikely to find a permanent place in the orchestra.

Third, the lack of knowledge and the unfamiliarity surrounding the saxophone made it vulnerable to attacks on its value and legitimacy as a musical instrument:

The saxophone is a long metal instrument bent at both ends. It is alleged to be musical. As regards markings, the creature has a series of tiny taps stuck upon it, apparently at random. These taps are very sensitive; when touched they cause the instrument to utter miserable sounds suggesting untold agony. Sometimes it bursts into tears. At either end there is a hole. People sometimes for no reason at all, blow down the small end of the saxophone which then shrieks and moans as if attacked by a million imps of torture. The shrieks issue from the large end. So do the moans. The saxophone comes from where the black-eyed Susans grow and coal-black mammies flourish. The consensus of opinion is that it should have stayed there. ${ }^{69}$

American composer Kent Kennan described the saxophone as having a 'blatant, wailing quality', and deemed it unlikely that it would ever become a regular member of the symphony orchestra. ${ }^{70} \mathrm{~A}$ London reviewer also remarked after an early performance of Vaughan William's Symphony No. 6 that the saxophone usually stands for nastiness in respectable music. ${ }^{71}$ Such negative attitudes towards the saxophone would not have helped its case for entering the symphony orchestra.

Fourth, the saxophone was often not considered a 'serious' instrument in music making. Rather, it was commonly associated with military bands and popular music. ${ }^{72}$ Wally Horwood further supports this by claiming that 'before the last decade of the nineteenth century, the saxophone's progress as a serious instrument was not impressive'. In this context Horwood is referring to the saxophone's progress as a serious instrument in a classical music setting. Horwood also states an interesting point

\footnotetext{
${ }^{69}$ Horwood, Adolphe Sax, 1814-94: His Life and Legacy, 165. Quote from The Golden Years, Vol. II, No. 23, April 1972, 46.

${ }^{70}$ Cottrell, The Saxophone, 229.

71 Ibid., 231.

72 Umble, Jean-Marie Londeix: Master of the Modern Saxophone, 98; 214; Horwood, Adolphe Sax, 181494: His Life and Legacy, 166-170.
} 
that composers were reluctant to write a saxophone part because they were worried it might not get played. Simultaneously, musicians were dissuaded from learning the saxophone because they thought nobody wrote for the instrument. ${ }^{73}$ In an interview with Eugene Rousseau, Marcel Mule expressed that there were still many people who only thought of the saxophone in terms of the jazz or popular music idiom. ${ }^{74}$ Londeix has also expressed his concerns about the saxophone's position in 'serious' music, stating that the saxophone's only hope for a place in 'serious' music is through modern music. Notably, Londeix believes that if saxophonists do not embrace the avant-garde as the most important music of the classical saxophone, the saxophone will face increasing irrelevance and eventual extinction in the classical musical world. ${ }^{75}$

Lastly, Cottrell also suggests that lack of competent players was a detrimental factor for composers writing for the saxophone. According to Cottrell, Edward Elgar intended to include a quartet of saxophones in his composition Canactacus. However, due to the difficulty and expense of finding suitable players this did not eventuate. ${ }^{76}$ Egnlish composer William Walton also expressed difficulty in finding suitable saxophonists for those works of his which included a saxophone part. ${ }^{77}$ In an interview with Eugene Rousseau, Marcel Mule shares a similar opinion on the matter:

I would say that the one most evident element of discouragement was that composers of the time did not write enough for the saxophone. I believe that they really thought there were not enough good saxophonists available. ${ }^{78}$ The effect of these five factors may well have contributed to the saxophone's non-establishment in the orchestra. By extension, they could also be seen to be reflected in the orchestral writing for the instrument. As demonstrated in the previous section, the saxophone has frequently featured as a solo voice in the orchestra. In some cases, it was only used as a solo voice. This positions the instrument as an

\footnotetext{
${ }^{73}$ Horwood, Adolphe Sax, 1814-94: His Life and Legacy, 166.

${ }^{74}$ Rousseau, Marcel Mule: His Life And The Saxophone, 80.

${ }^{75}$ Umble, Jean-Marie Londeix: Master of the Modern Saxophone, 108.

${ }^{76}$ Cottrell, The Saxophone, 229.

77 Ibid., 230.

78 Rousseau, Marcel Mule: His Life And The Saxophone, 78.
} 
'outsider' to the orchestra - as an instrument that is often treated differently from 'standard' or 'normal' orchestral instruments. 


\section{Debussy's Rapsodie: A Virtuosic Work?}

As explored in sections 2, 3 and 4, the use of the altissimo register, fast finger technique and the emphasis of a soloist role can be considered as virtuosic in the classical saxophone repertoire. This section analyses the manifestation of these virtuosic practices in Vincent David's and Eugene Rousseau's arrangements of Claude Debussy's Rapsodie for orchestra and alto saxophone and investigates why these practices may be contradictory to the composer's intentions.

Dynamics:

Several additions of louder dynamic markings can be observed in David's and Rousseau's arrangements of the Rapsodie. These increased dynamic levels work to audibly elevate the saxophone part above the orchestral parts, thus emphasising the saxophone part in a soloistic role.

Arrangement by Vincent David [Bar number in the original score: Description]

Bar 15-16: the diminuendo is removed from the saxophone part.

Bar 63: the diminuendo is removed from the saxophone part and replaced with a crescendo.

Bar 83: $p p$ dynamic is removed from the saxophone part. (The new dynamic level is now $p$ )

Bar 88: a crescendo is added to the saxophone part (originally violin I part).

Bar 96: $p$ dynamic is replaced with a $f$ dynamic in the saxophone part.

Bar 99-100: the diminuendo is removed from the saxophone part.

Bar 105-106: a crescendo is added to the saxophone part (originally muted trumpet part).

Bar 192: $p p$ dynamic is removed from the saxophone part. (The new dynamic level is now $f$ )

Bar 256: $m f$ dynamic is removed from the saxophone part. (The new dynamic level is now $f$ )

Bar 292: $f$ dynamic is replaced with a $f f$ dynamic in the saxophone part.

Bar 300: a crescendo is added to the saxophone part (originally oboe/clarinet parts). 
Bar 365: $f$ dynamic is replaced with a $f f$ dynamic in the saxophone part (originally French horn part).

Bar 369: $f$ dynamic is replaced with a $f f$ dynamic in the saxophone part (originally trombone part).

\section{Arrangement by Eugene Rousseau}

Bar 14: a crescendo is added to the saxophone part.

Bar 15: $m p$ dynamic is added to the saxophone part. (The previous marked dynamic is p)

Bar 16: the diminuendo in the saxophone part is delayed to bar 17.

Bar 28: $\mathrm{mf}$ dynamic is added to the saxophone part. (The previous marked dynamic is p)

Bar 33: a crescendo is added to the saxophone part.

Bar 99: the diminuendo is removed from the saxophone part.

Bar 105: $p$ dynamic is replaced with a $m p$ dynamic in the saxophone part (originally muted trumpet part).

Bar 119: $m p$ dynamic is added to the saxophone part (originally oboe part, at a $p$ dynamic).

Bar 127: $m p$ dynamic is added to the saxophone part (originally flute part, at a $p$ dynamic).

Bar 172: a brief crescendo is added to the saxophone part.

Bar 173: a brief crescendo is added to the saxophone part.

Bar 182: $p$ dynamic is replaced with a $m p$ dynamic in the saxophone part.

Bar 196: the diminuendo is removed from the saxophone part.

Bar 265: $p$ dynamic is replaced with a $m f$ dynamic in the saxophone part.

Re-orchestration:

In modern performances, saxophonists usually augment the solo part by playing passages that were originally written in the woodwind section to create more interest and virtuosity in the soloist's performance. ${ }^{79}$

\footnotetext{
${ }^{79}$ Graves, 'An Historical Investigation of and Performance Guide for Jacques Ibert's Concertino da Camera', 37.
} 
Further emphasising the saxophone in a soloist role is the re-orchestration of parts in these arrangements. David's arrangement takes material from the flute, oboe, cor anglais, clarinet, trumpet, French horn, trombone, violin and viola parts and gives it to the saxophone. As a result, this increases the saxophone's amount of playing time from 163 to 282 bars. Similarly, Rousseau's arrangement takes material from all of the same instruments which extends the saxophone's playing time to 271 bars. The extra 119 bars and 108 bars of playing time in David's and Rousseau's arrangements respectively, increase the saxophone's soloistic role by more than $50 \%$.

\section{Arrangement by Vincent David}

Bar 42-53: the oboe part is re-orchestrated for the saxophone.

Bar 87-88: the French horn part is re-orchestrated for the saxophone.

Bar 88: the violin I part is re-orchestrated for the saxophone.

Bar 93-94: the clarinet part is re-orchestrated for the saxophone.

Bar 94: the harp part is re-orchestrated for the saxophone.

Bar 102-103: the cor anglais part is re-orchestrated for the saxophone.

Bar 105-107: the muted trumpet part is re-orchestrated for the saxophone.

Bar 109-111: the muted trumpet part is re-orchestrated for the saxophone.

Bar 111-113: the cor anglais part is re-orchestrated for the saxophone.

Bar 114: the concert $D \#$ pitch in the flute and violin I parts is re-orchestrated for the saxophone.

Bar 115-123: the oboe part is re-orchestrated for the saxophone.

Bar 123-125: the clarinet part is re-orchestrated for the saxophone.

Bar 127-136: the flute part is re-orchestrated for the saxophone.

Bar 137-145: the flute/oboe parts are re-orchestrated for the saxophone.

Bar 158-165: the piccolo/flute/oboe/clarinet parts are re-orchestrated for the saxophone.

Bar 201-209: the oboe part is re-orchestrated for the saxophone.

Bar 273: the cor anglais part is re-orchestrated for the saxophone.

Bar 275-276: the cor anglais part is re-orchestrated for the saxophone.

Bar 293-294: the flute/violin parts are re-orchestrated for the saxophone. 
Bar 295-296: the oboe/clarinets parts are re-orchestrated for the saxophone.

Bar 297-298: the flute/violin parts are re-orchestrated for the saxophone.

Bar 299-300: the oboe/clarinets parts are re-orchestrated for the saxophone.

Bar 303-306: the oboe/cor anglais/clarinet/trumpet parts are re-orchestrated for the saxophone.

Bar 309-315: the oboe part is re-orchestrated for the saxophone.

Bar 316-317: the clarinet part is re-orchestrated for the saxophone.

Bar 317-322: the flute/cor anglais/clarinet parts are re-orchestrated for the saxophone.

Bar 323-332: the oboe part is re-orchestrated for the saxophone.

Bar 344-351: the piccolo/flute/oboe/clarinet parts are re-orchestrated for the saxophone.

Bar 365-367: the French horn parts are re-orchestrated for the saxophone.

Bar 369-371: the trombone part is re-orchestrated for the saxophone.

\section{Arrangement by Eugene Rousseau}

Bar 42-48: the oboe part is re-orchestrated for the saxophone.

Bar 48-53: the flute part is re-orchestrated for the saxophone. Notably, this passage sits in the lower/middle register of the flute, a register which naturally doesn't project as strongly as the flute's higher register. When this part is re-orchestrated for the saxophone, however, the passage sits in the saxophone's upper register. The change in register of this melody now makes it more audibly prominent than its original context. Bar 87-88: the French horn part is re-orchestrated for the saxophone.

Bar 88: the violin I part is re-orchestrated for the saxophone.

Bar 93-94: the clarinet part is re-orchestrated for the saxophone.

Bar 94: the harp part is re-orchestrated for the saxophone.

Bar 102-103: the cor anglais part is re-orchestrated for the saxophone.

Bar 105-106: the muted trumpet part is re-orchestrated for the saxophone.

Bar 109-110: the muted trumpet part is re-orchestrated for the saxophone.

Bar 115-117: the oboe part is re-orchestrated for the saxophone.

Bar 119-123: the oboe part is re-orchestrated for the saxophone. 
Bar 123: the clarinet part is re-orchestrated for the saxophone.

Bar 127-133: the flute part is re-orchestrated for the saxophone.

Bar 137-145: the flute/oboe parts are re-orchestrated for the saxophone.

Bar 150-157: the violin/viola parts are re-orchestrated for the saxophone.

Bar 158-165: the piccolo/flute/oboe/clarinet parts are re-orchestrated for the saxophone.

Bar 209: the second beat of the oboe part is re-orchestrated for the saxophone.

Bar 217-221: the flute/violin parts are re-orchestrated for the saxophone.

Bar 225-232: the flute/oboe/violin parts are re-orchestrated for the saxophone.

Bar 293-294: the flute/violin parts are re-orchestrated for the saxophone.

Bar 295-296: the oboe/clarinets parts are re-orchestrated for the saxophone.

Bar 297-298: the flute/violin parts are re-orchestrated for the saxophone.

Bar 299-300: the oboe/clarinets parts are re-orchestrated for the saxophone.

Bar 303-304: the piccolo/flute/violin parts are re-orchestrated for the saxophone.

Bar 307: the violin parts are re-orchestrated for the saxophone.

Bar 308: the flute parts are re-orchestrated for the saxophone.

Bar 309: the clarinet part is re-orchestrated for the saxophone.

Bar 323-331: the oboe part is re-orchestrated for the saxophone.

Bar 336-343: the violin/viola parts are re-orchestrated for the saxophone.

Bar 365: the French horn parts are re-orchestrated for the saxophone.

Bar 367: the French horn parts are re-orchestrated for the saxophone.

Bar 369: the trombone part is re-orchestrated for the saxophone.

Bar 371: the trombone part is re-orchestrated for the saxophone.

Bar 384: the flute part is re-orchestrated for the saxophone.

Altissimo:

As a result of this re-orchestration of parts, the saxophone is required to play several passages that enter the altissimo register.

\section{Arrangement by Vincent David}

Bar 120: the re-orchestration of the oboe part creates an altissimo $a b^{\prime \prime \prime}$ for the saxophone. 
Bar 140: the re-orchestration of the flute/oboe parts creates an altissimo ab"' for the saxophone.

Bar 207: the re-orchestration of the oboe part creates an altissimo g'"', a"', $g^{\prime \prime \prime}$ for the saxophone.

Bar 305: the re-orchestration of the oboe/cor/clarinet/trumpet parts creates an altissimo g"' for the saxophone.

Bar 312: the re-orchestration of the oboe part creates an altissimo $a b^{\prime \prime \prime}$ for the saxophone.

Bar 326: the re-orchestration of the oboe part creates an altissimo $a b^{\prime \prime \prime}$ for the saxophone.

\section{Arrangement by Eugene Rousseau}

Bar 120: the re-orchestration of the oboe part creates an altissimo $a b^{\prime \prime \prime}$ for the saxophone.

Bar 140: the re-orchestration of the flute/oboe parts creates an altissimo $a b^{\prime \prime \prime}$ for the saxophone.

Bar 326: the re-orchestration of the oboe part creates an altissimo $a b^{\prime \prime \prime}$ for the saxophone.

Although the Rousseau arrangement gives the saxophonist the option to avoid the altissimo register altogether by playing these passages down an octave, it still utilises a higher range and a more frequent use of high notes than the original: the original version uses $\mathrm{db}^{\prime \prime \prime}$ as the saxophone's highest note, which is only played once. The Rousseau version, on the other hand, requires the saxophone to play $\mathrm{d} \#^{\prime \prime \prime} / \mathrm{eb}^{\prime \prime \prime}, \mathrm{e}^{\prime \prime \prime}$, e\#"'"/f'" and ff"' on several occasions.

Faster technique:

The requirement of faster finger work in these arrangements is another result of the re-orchestration of parts. In the original version the saxophone is tacet during the first Allegretto Scherzando section (bar 39-53), and in the second Allegretto Scherzando (bar 85-169) it is only required to play crotchets and dotted crotchets over a duration of five bars. The David and Rousseau arrangements, however, feature the saxophone playing quick semiquaver flourishes and even faster semiquaver octuplet rhythms in 
these Allegretto Scherzando sections. Furthermore, these arrangements have the saxophone playing the fast semiquaver and sextuplet semiquaver rhythms in the Plus Vite section (bar 249-309) much more frequently. While the original version only has the saxophone playing these rhythms for a total of 5 bars, the Rousseau arrangement requires the saxophone to play these rhythms for a total of 17 bars and, in David's arrangement, for a total of 16 bars. The more frequent feature of fast finger work in these arrangements further reflects virtuosic sentiments.

The significance of these virtuosic practices is only fully appreciated when one considers Debussy's intentions for the Rapsodie. This thesis poses that Debussy's intentions were not for a virtuosic, concerted work, but rather for a work for orchestra and obligato saxophone. This is foremost reflected in the title naming process of the work. Originally called Fantaisie, the work was later changed to Rapsodie Orientale, Rapsodie Arabe, Rhapsodie Mauresque, and then finally to Rhapsodie (later corrected to Rapsodie). ${ }^{80}$ Further, Rapsodie is labelled as a work for 'orchestra and saxophone', rather than saxophone and orchestra. Although subtle, this ordering of words actually emphasises the orchestra's precedence over the saxophone. The opposite is demonstrated in Ibert's Concertino da Camera and Dubois' Concerto, where both works are labelled 'for saxophone and orchestra' because the saxophone plays the dominant role as a concerto soloist.

Secondly, the work's commissioner, Elise Hall, was an amateur musician. She began playing saxophone at the age of $47,{ }^{81}$ and helped found an amateur musician orchestral club in Boston. ${ }^{82}$ It is also thought that the reason she began playing the saxophone was to help her recover from typhoid fever. ${ }^{83}$ With this considered, Debussy may well have composed Rapsodie with Hall's amateur status in mind. Lastly, an array of similarities can be seen when comparing the works' melodic material with the chants and calls of French street vendors, as notated by French

\footnotetext{
${ }^{80}$ William Henry Street, 'Elise Boyer Hall, America's First Female Concert Saxophonist: Her Life as Performing Artist, Pioneer of Concert Repertory for Saxophone and Patroness of the Arts', D.M. diss., Northwestern University (1983), 47.

${ }^{81}$ Alex Fritz Powell, 'Organizational Identity in the History of the Longy School of Music', D.M.A. diss., Boston University (2014), 46.

${ }^{82}$ Cottrell, The Saxophone, 244.

83 Ibid., 243.
} 
composer and musicologist Georges Kastner in his book, Les voix de paris. ${ }^{84}$ These speech-like elements further emphasise a non-virtuosic standing as they command a declamatory approach to the music, rather than an approach that exudes virtuosity.

${ }^{84}$ Umble, Jean-Marie Londeix: Master of the Modern Saxophone, 213. 


\section{Investigating the Imposition of Virtuosic Adaptations in Debussy's Rapsodie}

Despite potential contradictions to the composer's original intentions, Debussy's Rapsodie has been subjected to a variety of adaptations which can be seen to heighten its degree of virtuosity. In this section, I direct an investigation into why these adaptations may have eventuated. I argue that the virtuosic adaptations imposed on Debussy's Rapsodie are indirect results of a negative discourse that surrounded the work, its commissioner Elise Hall, and the saxophone itself during the initial stages of the conception of the Rapsodie.

A letter dated 4 June 1903 from Debussy to his wife, Lilly, marks the beginning of this anti-Rapsodie discourse:

I do not know why "the Saxophone Lady" appears to me as the Statue of the commendatore appeared to poor Don Juan! - She will never suspect how much she bored me. Does it not appear indecent to you, a woman in love with a saxophone, whose lips sucks at the wooden mouthpiece of this ridiculous instrument? - That must surely be an old mole who dresses like an umbrella. ${ }^{85}$ At face value, this letter shows obvious signs of Debussy's disdain for the 'ridiculous' saxophone and the boring, 'old mole' Elise Hall. However, when one considers the wider context in which this letter was written, it can be understood that Debussy's disdain is disingenuous. A previous letter dated 8 September 1902 from Debussy to André Messager reveals a time of frustration and exhaustion for Debussy:

I have not written one note... In order to do what I want I must go off in a completely new direction. To begin a new work appears to me like a perilous leap, and one risks breaking one's back... for a long time I had been like a squeezed lemon, and my poor brain did not want to learn anything more. ${ }^{86}$ Furthermore, saxophonist and musicologist James Noyes points out in his article 'Debussy's Rapsodie pour orchestre et saxophone Revisited' that Debussy did not produce anything except a few articles of music criticism. ${ }^{87}$

\footnotetext{
${ }^{85}$ Cottrell, The Saxophone, 244.

86 James Noyes, 'Debussy's Rapsodie pour orchestre et saxophone Revisited', The Musical Quarterly 90/3-4 (2008), 420.

${ }^{87}$ Noyes, 'Debussy's Rapsodie pour orchestre et saxophone Revisited', 420-422.
} 
Next, in a letter to Messager dated 8 June 1903, Debussy expresses that he is 'searching desperately for novel combinations to show off this aquatic instrument' ${ }^{88}$ This is vital to understanding the context of Debussy's apparent disdain, as this shows his lack of knowledge about the instrument. A letter dated July 1903 to Pierre Louÿs further solidifies that Debussy knows little about the saxophone and how to write for it:

Forgive me... for some days I've been: the man-who's-working-on-a-Fantasyfor-Eb-alto-saxophone (try saying that three times without taking a breath...) Considering this fantasy was commissioned, paid for and spent more than a year ago, you could say I'm behindhand - For one thing the idea didn't interest me greatly, and for another I wouldn't otherwise have been able to write you such a fine letter. The saxophone is a reedy animal with whose habits I'm largely unfamiliar. Is it suited to the romantic sweetness of the clarinets or rather vulgar irony of the sarrusophone (or the contra-bassoon)? In the end I've got it murmuring melancholy phrases against rolls on the side-drum... ${ }^{89}$ Given that Debussy was enduring a period of exhaustion and frustration; that he had not composed any music in some time; that he had never before composed a work using the saxophone; and that the saxophone was an instrument he knew little about, it is not unreasonable to understand Debussy's disdain for Elise Hall and the saxophone as only superficial. His disdain was likely a mere manifestation of his frustration due to his trying circumstances at the time.

Another aspect of this negative discourse can be seen in a May 1919 review of Yves Mayeur's performance of Rapsodie in Le Monde Musicale. This review denounces Rapsodie as 'the work in which Debussy sounds least like himself' ${ }^{90}$ The notion of Rapsodie's apparent 'otherness' and the idea that the work is not Debussy-esque may stem from its apparent unfinishedness, and its posthumous realisation by French composer Jean Roger-Ducasse. These reasons, however, are

\footnotetext{
${ }^{88}$ Edward Lockspeiser, Debussy (London: J. M Dent \& Sons Ltd, 1980), 175.

${ }^{89}$ François Lesure and Roger Nichols, Debussy Letters, trans. Roger Nichols (Massachusetts: Harvard University Press, 1987), 107.

90 Noyes, 'Debussy's Rapsodie pour orchestre et saxophone Revisited', 417.
} 
unfounded. Due to Debussy's untimely death, before Rapsodie was officially published, Roger-Ducasse took it upon himself to create the orchestral score using Debussy's original, handwritten manuscript. Unfortunately, Roger-Ducasse's actions have been confused and misinterpreted by Leon Vallas, Debussy's biographer, as an act whereby Roger-Ducasse completed Debussy's 'rough draft' ${ }^{91}$ We can have confidence in RogerDucasse's realisation of Rapsodie as an accurate and authentic product of what Debussy envisioned. Firstly, Roger-Ducasse's orchestral score includes sixty-two of Debussy's original sixty-five indications which is a retention rate of 95 percent. ${ }^{92}$ In regards to the three alterations: the snare drum and tambourine rhythms at bar 39 were re-orchestrated for the tambourine and triangle respectively; and the muted trumpet part in bars $128-129$ and 132-133 was re-orchestrated for the clarinet and oboe. ${ }^{93}$ Roger-Ducasse was also very meticulous in the inclusion of Debussy's tempo markings and markings of performance techniques. ${ }^{94}$ Moreover, as Noyes underlines in his article, Roger-Ducasse had a deep understanding of Debussy's orchestration techniques. ${ }^{95}$ Roger-Ducasse's preparation work was also praised by Jean-Michel Nectoux, Fauré's biographer, as 'high quality by the French editorial standards of the time'. ${ }^{96}$ Further, both French composer Alfred Desenclos and Director of Éditions Durand Monsieur A. Riveau concluded in 1969 that the orchestration of Rapsodie was written by Debussy himself. ${ }^{97}$ Lastly, François Lesure, a prominent Debussy scholar, stated in a letter to Londeix that 'it is abusive to pretend that Roger-Ducasse "completed" the Rapsodie. It would be more accurate to call it "preparation for printing"' .98

Notwithstanding, various scholars have drawn similarities between the Rapsodie and other works by Debussy, further weakening Le monde musicale's

\footnotetext{
${ }^{91}$ Oscar Thompson, Debussy, Man and Artist (New York: Dover Publications, 1967), 147.

92 Noyes, 'Debussy's Rapsodie pour orchestre et saxophone Revisited', 429.

93 Ibid., 442.

94 Ibid., 429.

95 Ibid., 431.

96 Jean-Michel Nectoux, Gabriel Fauré: A Musical Life, trans. Roger Nichols (Cambridge: Cambridge University Press, 1991), 455-456.

97 Noyes, 'Debussy's Rapsodie pour orchestre et saxophone Revisited', 428.

98 Noyes, 'Debussy's Rapsodie pour orchestre et saxophone Revisited', 418.
} 
denouncement of the work. Londeix draws similarities between Rapsodie and Lindaraja (1901), having similar elements of repeated, strong unresolved dominant ninth chords; La Soirée dan Grenade from Estampes (1903) with a similar melancholy and dreamy introduction, mysterious calm, graceful habanera rhythm, and expressive grace notes; and Danses pour harpe et orchestra à cordes (1904) which has a similar bipartite form, and similar duration of $10^{\prime} 30^{\prime \prime} .{ }^{99}$ Further, a review of the first performance of Rapsodie in Winterthur, Switzerland in 1931 praises the work as a "colourful sound impression with a single great melodic span, where connections with Afternoon of a Faun are still shimmeringly audible, and whose figuration, harmony and orchestration already offer a glimpse of the later works La Mer and Iberia" ${ }^{100}$ And finally, in a letter dated 6 May 1918 to André Lambinet, Roger-Ducasse states a particular melody line in the Rapsodie as being reminiscent of the Adagio from Debussy's String Quartet. ${ }^{101}$

A third aspect of this negative discourse can be observed in a New York Times review of Raschèr's performance of Rapsodie on 11 November 1939:

It is far from [Debussy's] best effort, for the material, commonplace in itself, is ill-organised, and beyond the redemption of its expectedly fine orchestration. Debussy was scarcely stimulated by the instrument, for the Rhapsody does little to illuminate its peculiar capacities. And, as suggested in the program notes, he virtually begged his lack of interest by giving precedence to the orchestra in the title of the work, as well, indeed, as in the work itself. ${ }^{102}$ The reviewer's claim of Debussy's scarce stimulation and lack of interest in the saxophone is unjust - another example of the misinterpretation of Debussy's apparent disdain for the saxophone. Unfortunately, it is this sort of attitude that paints the Rapsodie as an inferior work. The criticism of the work giving precedence to the orchestra is also irrelevant. As discussed in section 6, Debussy's Rapsodie is not a concerted work, nor was it intended to be. Therefore, it is not a work that necessitates

\footnotetext{
${ }_{99}$ Umble, Jean-Marie Londeix: Master of the Modern Saxophone, 216.

${ }^{100}$ Noyes, 'Debussy's Rapsodie pour orchestre et saxophone Revisited', 417.

101 Ibid., 426.

102 Ibid., 419.
} 
a predominant soloist and subordinate accompaniment relationship. Rather, quite the opposite is true. Reviewer Albert Bernstein successfully captures the true nature of Rapsodie in his Le Courrier Musicale review of the 4 May 1919 premiere performance:

The Rapsodie pour Orchestre et Saxophone by the regretted Claude Debussy, does not, as you might imagine, take on the character of a concerted work. It appears, rather as an orchestral tableau in which the singular character of the principal instrument's timbre is chiefly displayed, unlike virtuoso writing, which does not show off this aspect. By the importance of its proportions, the richness of its colours, the rare zest of its musical quality, this work, which allies itself to the best which has been written by its author, is worthy of the Nocturnes and Images. ${ }^{103}$

As previously discussed, Roger-Ducasse created an orchestral score that was both extremely accurate and highly representative of what Debussy envisioned. RogerDucasse was able to do this because Debussy's handwritten manuscript already had all the information he required. Therefore, Roger-Ducasse's work should be seen as a careful realisation rather than a completion and orchestration of something unfinished. Yet Debussy's biographers, Oscar Thompson and Leon Vallas, have portrayed the Rapsodie in quite the opposite manner:

...in 1911, he made desultory efforts to orchestrate the work. Apparently abandoning the task in despair, he sent the rough draft, obviously incomplete, to Mrs. Hall. ${ }^{104}$

In 1911, he again set to work on the instrumentation. But he wrote nothing more than a rough draft on three or four staves, and in this form the work was delivered to Mrs. Hall. He had not the courage to finish the score: he even left some bars blank, and some of the 'bridges' incomplete. ${ }^{105}$

Moreover, according to Noyes, these claims are false. Noyes suggests that Vallas has in fact misconstrued Debussy's work Première Rhapsodie for Orchestra and Clarinet as

\footnotetext{
${ }^{103}$ Frederick Hemke, 'The Early History of the Saxophone', D.M.A. diss., University of Wisconsin (1975), 439.

104 Thompson, Debussy, Man and Artist, 147.

105 Leon Vallas, Claude Debussy: His Life and Works, trans. Marie O'Brien and Grace O'Brien (Oxford: Oxford University Press, 1933), 162.
} 
the Rapsodie for Orchestra and Alto Saxophone. The Première Rhapsodie was composed in 1910 and published in 1911 which fits in the time frame of Vallas' claim. However, there is no evidence of further work on the saxophone Rapsodie beyond 1903. Also, Elise Hall only came to possess this manuscript, now known as the Hall manuscript, in 1919. ${ }^{106}$

The compounding negativity of these unfounded claims only further positions the Rapsodie as an inferior work. It is of utmost importance to emphasise Debussy's apparent distaste for the saxophone and Elise Hall as only superficial. The perceived inferiority of the work, and the idea that the work was incomplete have often reduced the work to a lowly status when compared with Debussy's other compositions. The liberties saxophonists have taken in adapting Rapsodie, which heighten the work's difficulty and afford a stronger soloist role, could, therefore, be seen as an attempt to substantiate the work. The aim: that Rapsodie would gain the recognition and respect as a serious work in the classical saxophone repertoire.

${ }^{106}$ Noyes, 'Debussy's Rapsodie pour orchestre et saxophone Revisited', 425. 


\section{Final thoughts and Reflections}

Virtuosity has had an unprecedented significance in the classical saxophone repertoire. It has taken on several specific forms which can be observed in a variety of classical saxophone works. In the case of Ibert's Concertino da Camera, numerous opportunities to showcase virtuosic altissimo are offered to the performer. These features of altissimo, which are commonly believed to be the influence of Sigurd Raschèr, are marked ad lib. This suggests that the altissimo passages are not integral to the work and could be played down the octave if the performer wishes. The choice to perform the altissimo passages could, therefore, be seen as a choice to be more virtuosic. Similarly, in the cases of Dubois' Concerto and Glazunov's Concerto, the alternative cadenzas demonstrate faster finger technique than the original cadenzas. Thus, the choice to perform the alternative cadenzas over the original cadenzas can be seen as a choice to showcase higher virtuosity. Lastly, soloistic virtuosity has proven to be a prominent feature in much of the classical saxophone orchestra repertoire. The saxophone's strong soloistic nature in the orchestral repertoire could be seen as a reflection of the instrument's non-establishment in the orchestra and the circumstances and perceptions of the saxophone at the time of its invention. These virtuosic aspects of altissimo, fast finger technique, and strong soloistic writing can all be observed in the Eugene Rousseau and Vincent David arrangements of Claude Debussy's Rapsodie for orchestra and alto saxophone. This thesis, however, has argued that Debussy's intentions for Rapsodie were not of a virtuosic work, but rather a piece for orchestra with an obligato saxophone part. By examining the context of Rapsodie's conception and the negative perceptions that surrounded the work, the commissioner Elise Hall, and the saxophone itself, it could be interpreted that these higher virtuosic arrangements of Rapsodie were an act to substantiate the work-a response to negative perceptions to position the Rapsodie as a great work in the classical saxophone repertoire.

This thesis has also opened up the wider issue of why certain aspects in music are given a virtuosic label or associated with virtuosity; what is it about the experience and feeling of these aspects that provoke people to classify them as virtuosic? What 
aspects of music do people consider to be virtuosic, and for what reasons? How would someone go about explaining the meaning of virtuosity to someone not familiar with it? Further research could explore how one's background or position affects their experience of virtuosity, how a performer's point of view may vary from that of a listener, and how the perspective of a listener who has prior musical knowledge or experience differs from one who does not. Furthermore, is there a commonality between virtuosity's use in music and other art forms? Does an over-arching value tie different aspects of virtuosity together? In other words, do all forms of virtuosity stem from or link back to a particular value like competence, mastery or difficulty? Finally, what other specific aspects of virtuosity have been, or could be, applied to the classical saxophone repertoire or other instrumental repertoire, and what significance or effect do they have in this context? An exploration of such questions would further our understanding of virtuosity within the classical saxophone repertoire and more broadly. 


\section{Bibliography}

Anderson, Jack Erik. 'The Cellist's Right Hand: A Guidebook for Pedagogy and Practice'. D.M.A. diss., University of Idaho. 2001.

Berliner, Paul. Thinking in Jazz: The Infinite Art of Improvisation. Chicago: University of Chicago Press, 2009.

Berlioz, Hector. Berlioz's Orchestration Treatise: A Translation and Commentary, ed. Hugh MacDonald. Cambridge: Cambridge University Press, 2002.

Cochran, Alfred W. 'Reviewed Work: An American Tribute to Sigurd Raschèr by Lawrence Gwozdz'. American Music 20/2 (2002), 234-236.

Cottrell, Stephen. The Saxophone. New Haven: Yale University Press, 2012.

Cox, Arnie. 'Embodying Music: Principles of the Mimetic Hypothesis', Music Theory Online, 17/2, (2011)

<http://www.mtosmt.org/issues/mto.11.17.2/mto.11.17.2.cox.html> (accessed 11 November 2016).

De Villiers, Abraham Albertus. 'The development of the saxophone 1850-1950: its influence on performance and the classical repertory'. M.M. diss., University of Pretoria. 2014.

Deans, Kenneth. 'THE SAXOPHONE: A Soloist's Instrument'. American Music Teacher 24/6 (1975), 30-31.

Debussy, Claude. Rapsodie. Orchestral score, ed. Clinton F. Nieweg. Boca Raton: E.F. Kalmus, 1995.

Debussy, Claude. Rapsodie. Piano reduction score, arr. Eugene Rousseau. Saint Louis: Norruth Music, 1975.

Debussy, Claude. Rapsodie. Piano reduction score, arr. Vincent David. Paris: Editions Henry Lemoine, 2001.

Delange, Claude. 'Interview with the Legendary Marcel Mule on the History of Saxophone Vibrato'. Trans. Huguette Brassine (1998) < $\underline{\text { http://clarinet- }}$ saxophone.asn.au/wp-content/uploads/interview-with-Marcel-Mule.pdf> (accessed 8 August 2016). 
Dubois, Pierre Max. Concerto for Alto Saxophone and String Orchestra. Piano reduction score. Paris: Alphonse Leduc Editions Musicales, 1959.

Epstein, Andrew. Beautiful Enemies: Friendship and Postwar American Poetry. Oxford: Oxford University Press, 2006.

Gelles, George and Schmelz, Peter. 'Raschèr, Sigurd'. In Grove Music Online <http://www.oxfordmusiconline.com/subscriber/article/grove/music/22910> (accessed 18 October 2016).

Glazunov, Alexander. Concerto for Alto Saxophone and String Orchestra. Piano reduction score. Paris: Alphonse Leduc Editions Musicales, 1936.

Gooley, Dana. 'The Battle Against Instrumental Virtuosity'. In Franz Liszt and His World, ed. Christopher Gibbs and Dana Gooley. New Jersey: Princeton University Press, 2006. 75-112.

Graves, William Stuart. 'An Historical Investigation of and Performance Guide for Jacques Ibert's Concertino da Camera'. D.M.A. diss., University of Texas. 1998. Hemke, Frederick. 'The Early History of the Saxophone'. D.M.A. diss., University of Wisconsin. 1975.

Horwood, Wally. Adolphe Sax, 1814-94: His Life and Legacy. Baldock: Egon Publishers Ltd, 1983.

Howard, Vernon A. 'Virtuosity as a Performance Concept: A Philosophical Analysis'. Philosophy of Music Education Review 5/1 (1997), 42-54.

Hunt, Leigh. 'Paganini, the Spectacular Virtuoso'. In Music in the Western World: A History in Documents, ed. Piero Weiss and Richard Taruskin. Second edition. Belmont: Thomson Schirmer, 2008. 289-291.

Hutchings, Arthur. 'Concerto'. In Grove Music Online

<http://www.oxfordmusiconline.com/subscriber/article/grove/music/40737> (accessed 11 December 2016). Lauba, Christian. Cadenza for the Concerto for Alto Saxophone and String Orchestra by Alexander Glazunov. Paris: Alphonse Leduc Editions Musicales, 2010. Ibert, Jacques. Concertino da Camera. Piano reduction score. Paris: Alphonse Leduc Editions Musicales, 1935. 
Lesure, François and Nichols, Roger. Debussy Letters, trans. Roger Nichols.

Massachusetts: Harvard University Press, 1987.

Ingham, Richard. The Cambridge Companion to the Saxophone. Cambridge: Cambridge University Press, 1999.

Irving, John. 'Dazzling Concertos'. Early Music 34/3 (2006), 487-489.

Lockspeiser, Edward. Debussy. London: J. M Dent \& Sons Ltd, 1980.

Mauskapf, Michael. 'Collective Virtuosity in Bartók's Concerto for Orchestra'. Journal of Musicological Research 30/4 (2011), 267-296.

McLaughlin, Kevin. 'Reviewed Work: Virtuosity of the Nineteenth Century: Performing Music and Language in Heine, Liszt, and Baudelaire by Susan Bernstein'. Comparative Literature 53/2 (2001), 181-182.

Monteiro, Francisco. Virtuosity: Some (quasi phenomenological) thoughts. Porto:

European Conservatories Association, 2007.

Nectoux, Jean-Michel. Gabriel Fauré: A Musical Life, trans. Roger Nichols. Cambridge: Cambridge University Press, 1991.

Noyes, James. 'Debussy's Rapsodie pour orchestre et saxophone Revisited'. The Musical Quarterly 90/3-4 (2008), 415-445.

Pachet, François. 'Musical Virtuosity and Creativity'. In Computers and Creativity, ed. by Jon McCormack and Mark d'Inverno. Berlin: Springer Science \& Business Media, 2012. 115-146.

Pincherle, Marc. 'Virtuosity'. The Musical Quarterly 35/2, trans. Willis Wager (1949), 226-43.

Powell, Alex Fritz. 'Organizational Identity in the History of the Longy School of Music'. D.M.A. diss., Boston University. 2014.

Ramsey, Guthrie. The Amazing Bud Powell: Black Genius, Jazz History, and the Challenge of Bebop. Oakland: University of California Press, 2013.

Raschèr, Sigurd. Top-Tones for the Saxophone: Four-Octave Range. Third edition. New York: Carl Fischer Music, 1983. 
Raumberger, Claus and Ventzke, Karl. 'Saxophone'. In Grove Music Online

<http://www.oxfordmusiconline.com/subscriber/article/grove/music/24670>

(accessed 18 October 2016).

Rousseau, Eugene. Marcel Mule: His Life And The Saxophone. Shell Lake: Etoile Music, 1982.

Rousseau, Eugene. Saxophone High Tones. Second edition. St. Louis: Lauren Keiser Music Publishing, 2002.

Rowland, Hazel. 'Concert Review: Proms 2: A tentative orchestra but a dazzling soloist' (2014) < https://bachtrack.com/de DE/review-proms-china-philharmonic-balsom-july2014> (accessed 11 November 2016).

Stefaniak, Alexander. Schumann's Virtuosity: Criticism, Composition, and Performance in Nineteenth-Century Germany. Bloomington: Indiana University Press, 2016.

Street, William Henry. 'Elise Boyer Hall, America's First Female Concert Saxophonist:

Her Life as Performing Artist, Pioneer of Concert Repertory for Saxophone and Patroness of the Arts'. D.M. diss., Northwestern University. 1983.

The Editors of Encyclopædia Britannica. 'Sigurd Raschèr'. In Encyclopaedia Britannica Online <https://www.britannica.com/biography/Sigurd-Rascher> (accessed 18 October 2016).

Thompson, Oscar. Debussy, Man and Artist. New York: Dover Publications, 1967.

Umble, James C. Jean-Marie Londeix: Master of the Modern Saxophone. New Jersey:

Roncorp Publications, 2000.

Vallas, Leon. Claude Debussy: His Life and Works, trans. Marie O'Brien and Grace

O’Brien. Oxford: Oxford University Press, 1933.

Walser, Robert. 'Eruptions: Heavy Metal Appropriations of Classical Virtuosity'. Popular Music 11/3 (1992), 263-308. 


\section{Appendix}

\section{Original Cadenza From The Dubois Concerto}

Pierre Max Dubois

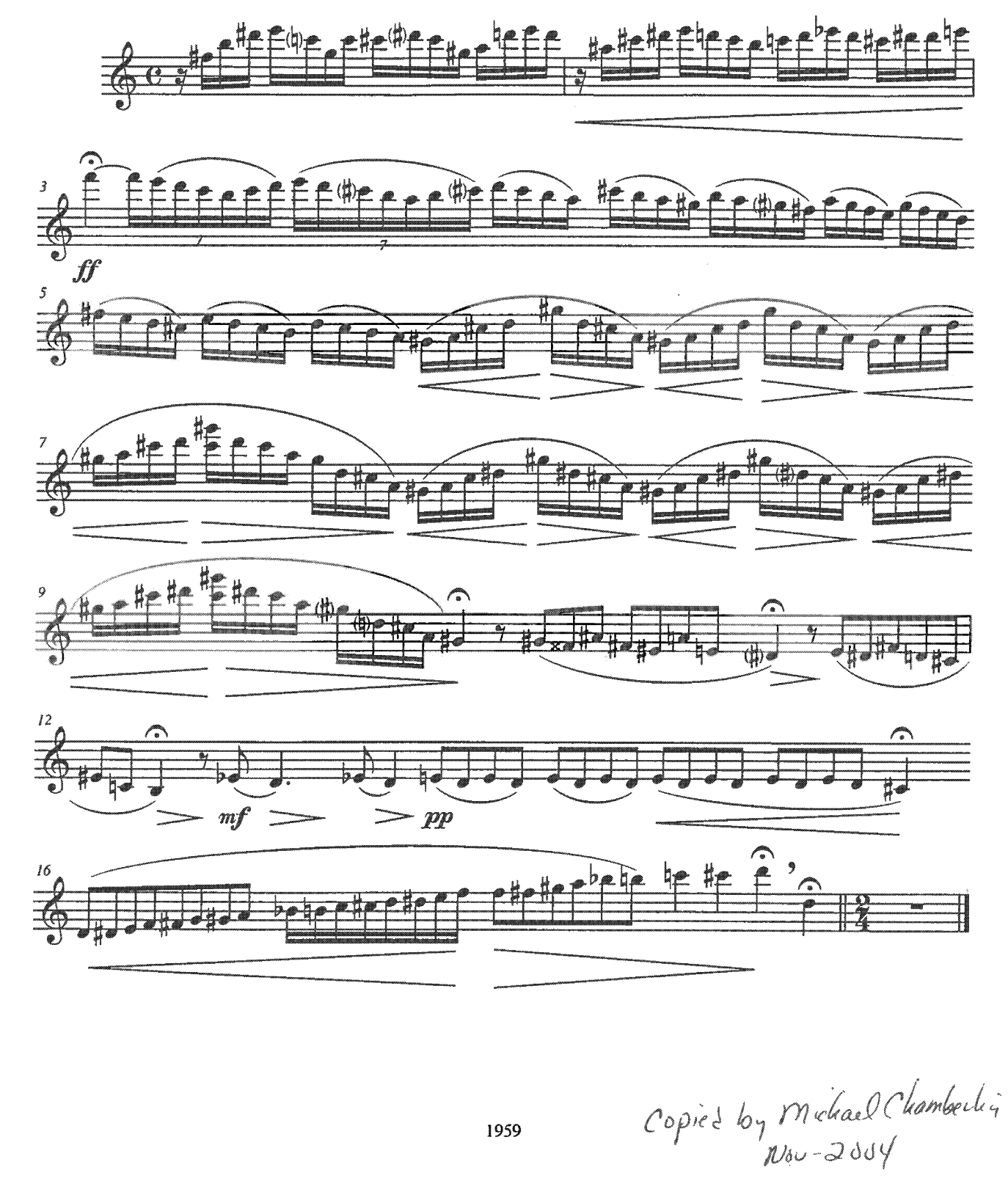

Original cadenza, Concerto by Pierre Max Dubois - transcribed by Michael Chamberlain

Note: After consulting Chamberlain's transcription (above) and two other manuscripts, which are thought to be written by Londeix, I believe that the $\mathrm{D} \sharp$ in bar 9 and the $\mathrm{E}^{\natural}$ in 
bar 12 in Chamberlain's transcription should, in fact, be a D\# and a Eb respectively. The second group of four quavers in bar 12 (Eb-D- Eb-D) should also be semiquavers, and the third and fourth groups of quavers should be demisemiquavers. These changes are present in my transcription of the cadenza on page 16. 